\title{
OECD Economic Policy Papers
}

No. 04

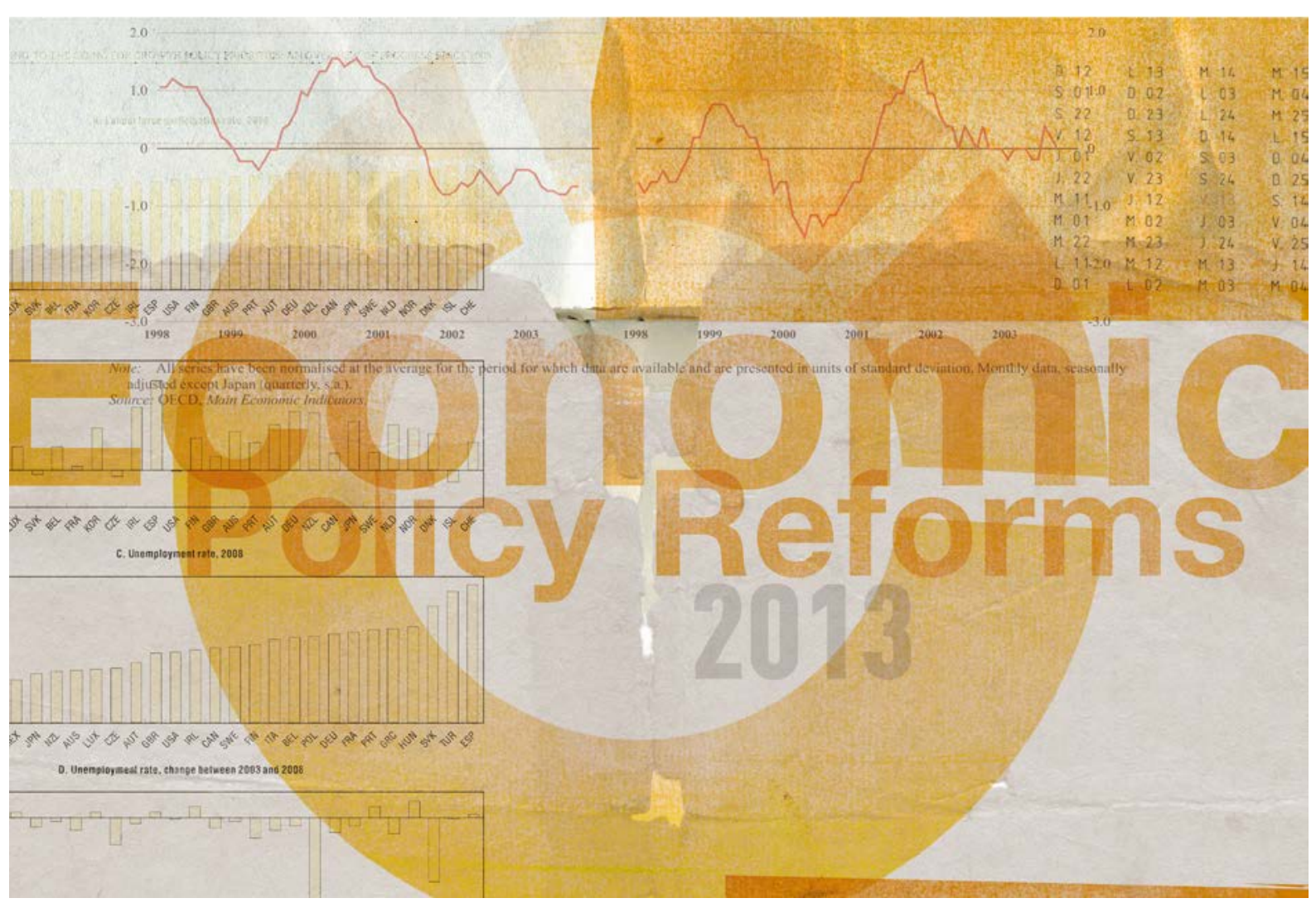

MAY 2013

\section{Knowledge-based capital, innovation and resource allocation}

A GOING FOR GROWTH REPORT 



\section{Knowledge-based capital, innovation and resource allocation}

This paper has been prepared by:

Dan Andrews

Chiara Criscuolo 
The OECD EConomic Policy Paper Series is published on the responsibility of the Secretary-General of the OECD. The opinions expressed and arguments employed herein do not necessarily reflect the official views of the Organisation or of the governments of its member countries.

This paper was written by Andrews, D, and C. Criscuolo under the supervision of Nicoletti, G. and Pilat, D. Statistical analysis and modelling support was provided by Chapuis, C., Westmore, B., C. Menon, P. Gal and M. Bas.

An earlier version of this paper was discussed at the Working Party 1 of OECD Economic Policy Committee and the Committee on Industry, Innovation and Entrepreneurship. The authors would like to thank the participants.

More detailed information is available from Andrews, D. and C. Criscuolo, 2013, Knowledge Based Capital, Innovation and Resource Allocation, Economics Department Working Papers No. 1046, OECD, Paris.

Series: OECD Economic Policy Papers ISSN 2226583X

This document and any map included herein are without prejudice to the status of or sovereignty over any territory, to the delimitation of international frontiers and boundaries and to the name of any territory, city or area.

The statistical data for Israel are supplied by and under the responsibility of the relevant Israeli authorities. The use of such data by the OECD is without prejudice to the status of the Golan Heights, East Jerusalem and Israeli settlements in the West Bank under the terms of international law.

(c) OECD 2013

You can copy, download or print OECD content for your own use, and you can include excerpts from OECD publications, databases and multimedia products in your own documents, presentations, blogs, websites and teaching materials, provided that suitable acknowledgment of OECD as source and copyright owner is given. All requests for public or commercial use and translation rights should be submitted to rights@oecd.org. Requests for permission to photocopy portions of this material for public or commercial use shall be addressed directly to the Copyright Clearance Center (CCC) at info@copyright.com or the Centre français d'exploitation du droit de copie (CFC) at contact@cfcopies.com. 


\section{Table of contents}

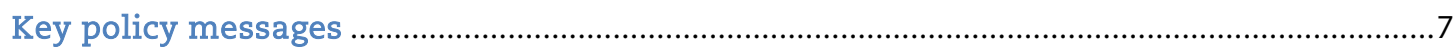

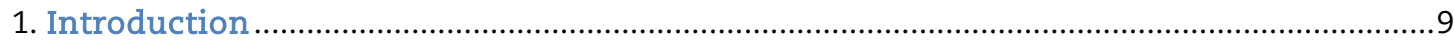

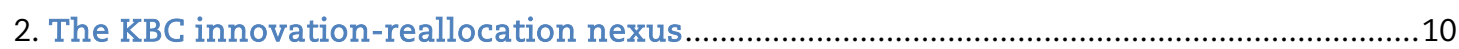

2.1 Efficient resource allocation in a knowledge-based economy ……......................................10

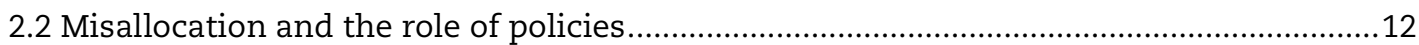

2.3 Side effects of the knowledge-based economy ….............................................................

3. Investment in $\mathrm{KBC}$, reallocation and productivity growth.................................................14

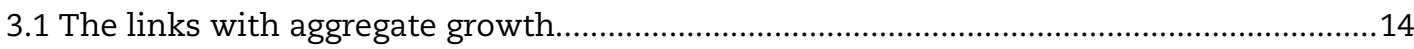

3.2 From macro to micro: KBC innovation and resource allocation........................................19

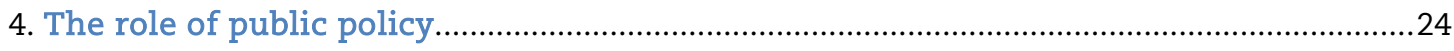

4.1 Framework policies have pervasive impacts on the KBC innovation-reallocation nexus25

4.2 Innovation-specific are policies are important but trade-offs emerge ................................31

4.3 Financing and corporate reporting in the knowledge-based economy ..............................40

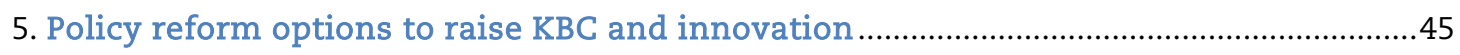

5.1 Appropriate framework policies raise the returns to investing in $\mathrm{KBC}$..............................45

5.2 Rethinking innovation policies by focusing on policy design .............................................45

5.3 Trade-offs between KBC and other policy priorities ..........................................................46

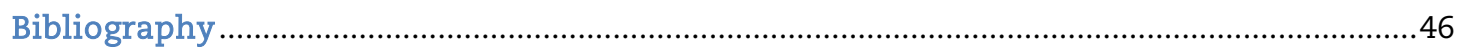

Boxes

Box 1. The scope for misallocation of $\mathrm{KBC}$ is significant .........................................................10

Box 2. Treatment of intangible assets in International Accounting Standards (IAS)...................41 


\author{
Abstract / Résumé \\ Knowledge-based capital, innovation and resource allocation
}

Investment in knowledge-based capital (KBC) - assets that have no physical embodiment, such as computerised information, innovative property and economic competencies - has been rising significantly. This has implications for innovation and productivity growth and requires new thinking on policy. The returns to investing in KBC differ significantly across countries and are partly shaped by structural policies, which influence the ability of national economies to reallocate scarce resources to firms that invest in KBC. In this regard, well-functioning product, labour and venture capital markets and bankruptcy laws that do not overly penalise failure can raise the expected returns to investing in $\mathrm{KBC}$ by improving the efficiency of resource allocation. While structural reforms offer the most cost-effective approach to raising investment in $\mathrm{KBC}$, there is a role for innovation policies to raise private investment in KBC towards socially optimal levels. Indeed, R\&D tax incentives and, as a finding that contrasts with previous research, direct support measures can be effective, but design features are crucial in order to minimise the fiscal cost and unintended consequences of such policies. Well-defined intellectual property rights (IPR) are also important to provide firms with the incentive to innovate and to promote knowledge diffusion via the public disclosure of ideas. However, such IPR regimes need to be coupled with pro-competition policies to ensure maximum effect while the rising costs of the patent system in emerging KBC sectors may have altered the trade-off inherent to IPR between the incentives to innovate and the broad diffusion of knowledge.

JEL classification codes: L20; O30; O40.

Key words: Intangible assets; innovation; reallocation; growth

\title{
Actifs intellectuels, innovation et mobilité des ressources
}

L'investissement dans le capital intellectuel - c'est-à-dire dans des actifs incorporels tels que les données informatisées, le capital d'innovation et les compétences économiques, ne cesse de progresser. Ces développements ont des implications pour l'innovation et l'accroissement de la productivité et exigent de repenser l'action des pouvoirs publics. Le rendement de l'investissement dans le capital intellectuel diffère sensiblement d'un pays à l'autre et est en partie formé par les politiques structurelles qui influent sur la capacité des économies à réaffecter les ressources limitées dans les entreprises qui investissent dans le capital intellectuel. Le bon fonctionnement des marchés des biens et services, du travail et de capital risque, ainsi qu'une législation sur le règlement des faillites ne pénalisant pas excessivement l'échec, peuvent augmenter les rendements attendus des investissements dans le capital intellectuel en améliorant l'efficacité de l'allocation des ressources. Si les réformes structurelles constituent l'approche la plus rentable pour accroitre les investissements dans le capital intellectuel, les politiques d'innovation peuvent jouer un rôle dans l'augmentation de l'investissement privé dans le capital intellectuel à un niveau plus optimal pour la collectivité. En effet, les incitations fiscales en faveur de la R-D ainsi que les mesures de soutien direct, peuvent être des dispositifs efficaces ; cependant, leur élaboration et mise en œuvre est cruciale afin de minimiser le coût fiscal et les conséquences non souhaitées de ces politiques. Des droits de propriété intellectuelle (DPI) bien définis sont également essentiels pour inciter les entreprises à innover et à promouvoir la diffusion des connaissances par la divulgation publique des idées. Toutefois, les régimes des droits de propriété intellectuelle doivent être associés à des politiques stimulant la concurrence pour en assurer un effet maximal, dans un contexte où les coûts croissants du système de brevets dans les domaines émergents du capital intellectuel ont affecté l'équilibre entre les incitations à innover et une diffusion plus large du savoir, inhérent aux DPI.

Classification JEL : L20 ; $030 ; 040$.

Mots clefs : Les immobilisations incorporelles ; l'innovation ; la réaffectation ; croissance.. 


\title{
Knowledge-based capital, innovation and resource allocation
}

\author{
Key policy messages
}

- Investment in knowledge based capital (KBC) - assets that have no physical embodiment such as computerised information, innovative property and economic competencies - has been rising, and in some countries is larger as a share of GDP than investment in physical capital. This has implications for innovation and productivity growth and requires new thinking on policy.

- There are important differences across OECD and emerging economies in the use of - and returns from - investment in KBC. As a share of GDP, and by way of examples based on the available data, the United States and Sweden invest about twice as much in KBC as Italy and Spain.

- Some countries are more successful than others at reallocating tangible resources to firms that invest in KBC. For example, the ease with which firms that patent (one indicator of innovative capacity) can attract capital - as measured by the elasticity of firm tangible capital with respect to patenting - in the United States and Sweden is much higher than for similar firms in Italy and Spain. This is especially the case for young firms that are more likely to experiment with radical innovations.

- Given the inherent difficulties in allocating KBC efficiently, policies that facilitate the redeployment of tangible resources take on heightened importance. Specifically, well-functioning product, labour and capital markets and bankruptcy laws that do not overly penalise failure can raise the expected returns to investing in KBC. These benefits are partly realised through stronger competitive pressures and more efficient reallocation, which make it easier for successful firms to implement and commercialise new ideas and, by lowering the costs of failure, encourage firms to experiment with uncertain growth opportunities.

- The liberalisation of barriers to international trade and investment raises the returns to innovation by expanding market size and encouraging more efficient resource allocation. Openess to trade and investment also increases the scope for knowledge diffusion across borders and these benefits are maximized by pro-competition product market regulations, which raise the incentives for firms to incorporate foreign technologies.

- Countries employ a range of innovation policies to raise private investment in innovation-related KBC towards more socially optimal levels, but the reliance on research and development (R\&D) tax incentives - compared with direct support measures - has increased dramatically over recent decades.

- While R\&D tax incentives can be effective at raising R\&D, the design of such schemes warrant attention in order to minimise the cost to tax payers and the tendency of such policies to favour less dynamic incumbents at the expense of dynamic young firms. R\&D tax incentives that are refundable and contain carry-over provisions are likely to be more effective and better meet the needs of young firms. Closer attention to the effects of cross-border tax planning strategies of multinational enterprises on the cost-effectiveness of such measures is also warranted. It is also important that governments do not repeatedly tinker with such policies, in order to minimise policy uncertainty for firms.

- More tentatively, there is clearer evidence than in the past that direct government support has a positive impact on innovation, possibly reflecting recent improvements in the design of such schemes. Thus, there may be a case for countries to make more use of direct innovation support measures. Public funding of basic research and institutional frameworks that foster collaboration in innovative activities are also important innovation policy tools. 
- Well-defined and high quality intellectual property rights (IPR) support the development of knowledge markets, promote knowledge diffusion via the public disclosure of ideas and provide firms with the incentive to innovate. However, such IPR regimes need to be coupled with procompetition policies and efficient judicial systems to ensure maximum effect. The rising costs of the patent system (e.g. from risk of litigation) in emerging KBC sectors, however, may have altered the trade-off inherent to IPR between the incentives to innovate and the broad diffusion of knowledge.

- $\mathrm{KBC}$ assets are difficult to collateralise and accounting frameworks for intangibles are inadequate to generate sufficient corporate disclosure in order to facilitate the flow of credit to KBC-intensive firms. One possible policy response is for governments to introduce guidelines for the voluntary reporting of intangible assets.

- Mechanisms to improve the allocation of $\mathrm{KBC}$ will become increasingly important. In this regard, equity financing - especially at the seed and early stage - plays an important role. There are ongoing efforts to develop the market for seed and early stage financing through a variety of supply-side policy initiatives, but evidence on their effectiveness is scarce. Framework conditions are in any case crucial in this respect. 


\section{Introduction}

Innovation-based growth, underpinned by investments in a broad range of $\mathrm{KBC}$, is central to raising long-term living standards. This is especially the case in advanced economies that are relatively close to the technological frontier where future growth will increasingly need to come from improvements in multi-factor productivity (OECD, 2012).

While investment in innovation has traditionally been proxied by a few indicators, such as spending on R\&D and the purchase of capital embodying new technologies, innovation-based growth relies on a much broader range of knowledge-based (KB) assets. These include employee skills, organisational know-how, databases, design, brands and various forms of intellectual property, and have been classified more formally under three broad categories, i.e. computerised information, innovative property and economic competencies (Corrado et al., 2005; Table 1).

Table 1. The classification of KBC and their possible effects

\begin{tabular}{|c|c|}
\hline Type of KBC asset & Mechanisms of output growth for investor in the asset \\
\hline \multicolumn{2}{|l|}{ Computerised information } \\
\hline Software & Improved process efficiency, optimised vertical and horizontal integration \\
\hline Databases & $\begin{array}{l}\text { Better market segmentation and appropriation of consumers' rent. Optimised vertical and horizontal } \\
\text { integration. The use of information to information to improve logistics and production efficiency }\end{array}$ \\
\hline \multicolumn{2}{|l|}{ Innovative property } \\
\hline Research \& Development & $\begin{array}{l}\text { New products and services. Quality improvements to existing ones. Better ways of producing } \\
\text { output. New technologies. }\end{array}$ \\
\hline Copyright and license costs & Knowledge diffusion (inventions and innovative methods). \\
\hline $\begin{array}{l}\text { New product development in the } \\
\text { financial industry }\end{array}$ & More accessible capital markets. Reduced information asymmetry and monitoring costs. \\
\hline $\begin{array}{l}\text { New architectural and engineering } \\
\text { designs }\end{array}$ & $\begin{array}{l}\text { Fixed cost leading to production in future periods. Quality improvements, novel designs, enhanced } \\
\text { processes. }\end{array}$ \\
\hline \multicolumn{2}{|l|}{ Economic competencies } \\
\hline Brand-building advertisement & Price premium. Increased market share. Changes in consumers' preferences. \\
\hline Market research & Targeted products and services. Increased market share. \\
\hline Workers' training & Improved production capability of workers. Increased skill levels. \\
\hline Management consulting & Faster and better decision making. Improved production processes. \\
\hline Own organisational capital & Faster and better decision making. Improved production processes. \\
\hline
\end{tabular}

Source: OECD, based on the classification in Corrado et al., (2005).

There are important differences across OECD economies in the investment in - and returns from - KBC and innovative capacity, which cannot solely be explained by differences in specialisation patterns (Section 3). These differences at the country level are associated with diverging patterns of firm performance within countries, with some countries being more successful at channelling resources to innovative and high growth firms than others. In this context, a key question is the extent to which national institutions and international arrangements can facilitate the reallocation of resources to new sources of growth based on KBC. Accordingly, this paper explores how public policies shape patterns of resource allocation and investment in $\mathrm{KBC}$, and the role of reallocation 
mechanisms in promoting the growth of innovative firms. More broadly, these issues have relevance for emerging economies aiming to move up the global value chain.

\section{The KBC innovation-reallocation nexus}

Recent research emphasises the growing importance of $\mathrm{KBC}$ as a source of productivity gains, and the contribution of efficient resource allocation to this process (Andrews and de Serres, 2012). Indeed, the non-rivalrous nature of knowledge means that the initial cost incurred in developing new ideas - typically through R\&D - does not get re-incurred as the latter are combined with other inputs in the production of goods or services. This gives rise to increasing returns to scale the important property that makes ideas and knowledge an engine of growth (Jones, 2005). Realising this growth potential, however, depends on the ability to reallocate labour and capital to their most productive use, and efficient mechanisms to reallocate tangible resources take on heightened importance, given that $\mathrm{KBC}$ is prone to misallocation (Box 1).

\section{Box 1. The scope for misallocation of $\mathrm{KBC}$ is significant}

Given the limitations of market mechanisms for allocating intangibles, KBC is prone to misallocation. The heterogeneous nature of $\mathrm{KBC}-$ e.g. patents are far from homogenous goods presents a key barrier to the efficient allocation of KBC via market mechanisms. Efficient outcomes would require transparent environments where there are opportunities to trade with a wide range of potential transactors (i.e., markets are thick), thereby creating the pre-conditions for effective matching (see Roth, 2008). However, the prices of transactions in the secondary market for patents are often not publicly disclosed, which exacerbates information asymmetries, undermining the development of a more liquid market. It is also unclear to what extent transactions in the secondary market allocate patents to more productive uses, especially in the IT sector given the rise of patent aggregators (Section 4.2.4). Similarly, the bilateral environment in which the details of a license are negotiated lack a transparent price discovery process to reveal the "fair" price of the patent and risk a poor quality match. Partly because of this, facilitating transactions in the market for patents is difficult and the market is subject to significant transaction costs (Gambardella, 2008; Eisenberg and Ziedonis, 2010).

Since tacit knowledge is embodied in individuals, it lacks separability which in turn undermines its transferability. Thus, the mechanisms for allocating tacit, human-capital based, or even codified but not legally protected KBC are even less efficient. In this setting, firms have two main options: corporate takeovers or selective recruitment (poaching) of specialists. However, both of these strategies entail important risks. For instance:

- A company acquiring an entity in which most intangible assets are human capital-based has to ensure the retention of the employees of interest (and their teams) in the postacquisition environment. This is a particularly risky proposition given the capital outlays involved and the fact that the acquiring company has less than perfect control of the targeted asset, since it is embedded in individuals.

- Accessing external sources of KBC via the selective recruiting of specialists is complicated by the usual obstacles to labour mobility - e.g. binding non-compete covenants and pension and health care portability - and the requirement that recruiting firms possess at least some internally-generated technological knowledge in order to effectively assess these external sources and to absorb the acquired knowledge.

\subsection{Efficient resource allocation in a knowledge-based economy}

Figure 1 sketches the key elements of the KBC-innovation-reallocation nexus. At the core of the framework are three inter-related building blocks, which broadly align with the different stages of the 
innovation process - (1) the development of new ideas (or adaptation of foreign technologies); (2) the implementation and commercialisation phase; and (3) reaping the benefits of new ideas through changes in market share and profitability. Of course, the framework takes as given a number of enabling factors - such as workforce skills - which are clearly crucial to innovation but are beyond the scope of the paper. ${ }^{1}$

Figure 1. The $\mathrm{KBC}$-innovation-reallocation nexus and public policies

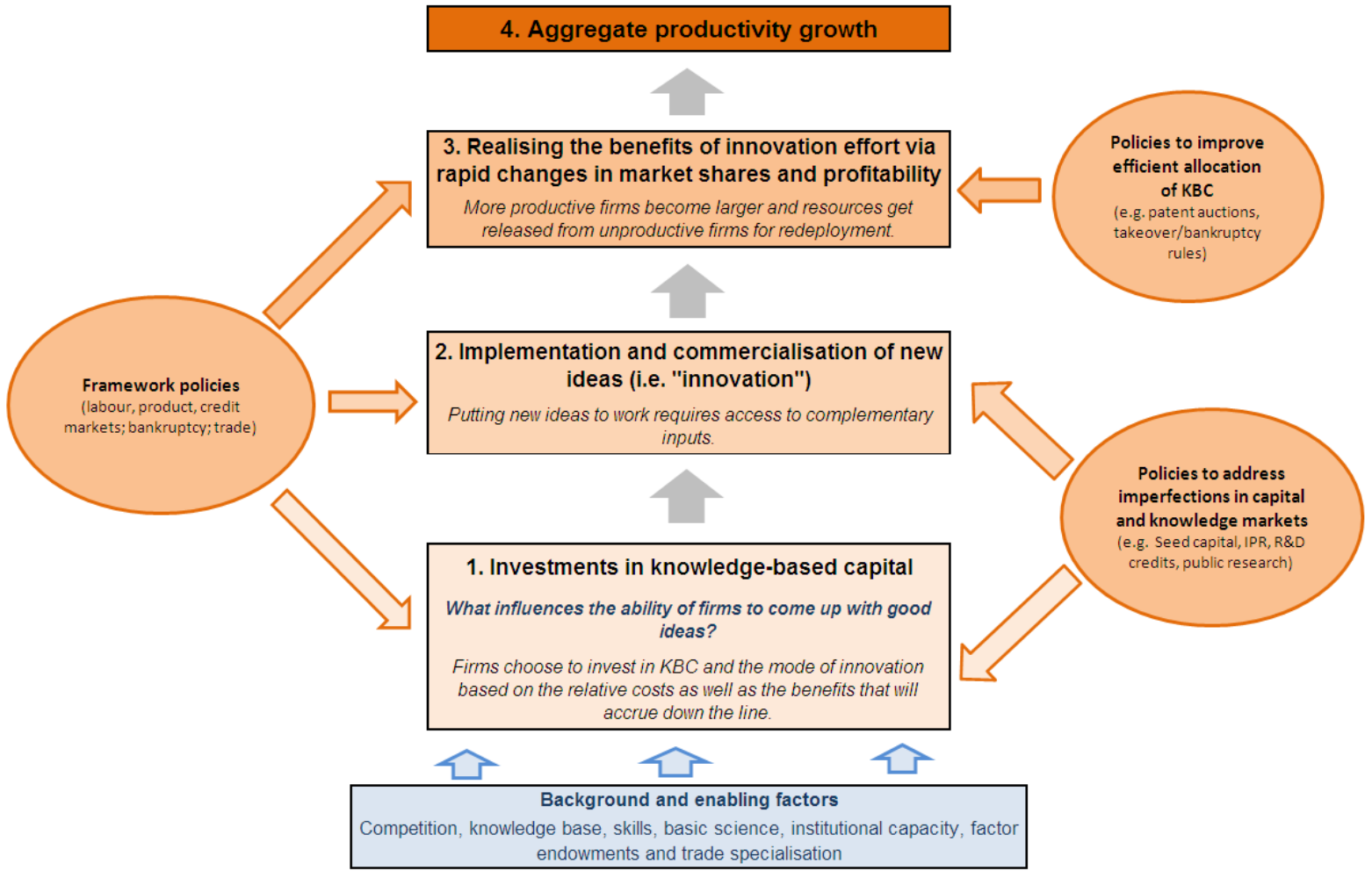

Implementing new ideas (in stage 2) can take the form of new processes and new organisations, which will allow the firm to produce more outputs with the same amount of inputs, and increase multi-factor productivity (MFP), thus lowering marginal costs of production. Ultimately, firms will be able to offer their outputs at a lower price and gain market shares through price competition (in stage 3). Innovations can also entail the introduction of new goods or quality improvements to existing goods, allowing firms to compete on quality (e.g. charging higher prices for their new or differentiated product without losing market shares). In the short to medium term, innovations will therefore increase firm's profitability (Geroski et al., 1993), but as other firms will also compete on quality, the profit margins gained by the firm with each single innovation are likely to be steadily eroded in well-functioning markets. ${ }^{2}$

The policy levers to boost the supply of skills in an economy are discussed at length in OECD (2012).

2 The introduction of new or improved goods might also lead to an increase in measured multi-factor productivity (MFP) if MFP is based on sales rather than physical output and, thus, an increase in price will lead to an increase in revenue based MFP. Most product innovations are also associated with process innovations (OECD, 2010) which, as discussed above, are directly linked with an increase in (quantity based measures of) MFP. 
Removing obstacles to experimentation with new products, processes and business models encourages investment in $\mathrm{KBC}$ - leading for instance to the efficient exploitation of information and communications technology (ICT) and large volumes of data (so-called "big data") - by both start-ups and incumbent firms operating at the frontier, who have to face competitive pressures. The competitive edge gained in this way and the appropriation of any returns from the firms' successful innovations justify ex ante their innovative efforts (Schumpeter, 1942). Furthermore, competition pushes frontier firms to continue to innovate to stay abreast of new technological developments (Aghion and Howitt, 1992), while further away from the frontier, investments in KBC are also necessary to facilitate adoption of the most productive technologies (Griffith et al., 2004). Firms that fail to do so may have to downsize or exit the market, releasing resources for use by firms producing with the most efficient technologies. Ultimately, via this market mechanism, the most productive firms will end up having the largest market shares, making resource allocation more efficient (Olley and Pakes, 1996) and the largest gains in efficiency will be realised when innovative firms can rapidly gain market share at the expense of unsuccessful or stagnant competitors (Bartelsman and Hinloopen, 2005).

The ability to rapidly expand the tangible capital base and the workforce is particularly important in a knowledge-based economy. Indeed, for firms that invest in KBC the profitability of successful new ideas depends on the possibility to exploit the strong returns to scale that characterise this type of capital (Bartelsman et al., 2010; Bartelsman and Groot, 2004). Scaling-up innovative production methods (e.g. ICT-related business investments) after they have shown success in smaller-scale experiments is one example (Brynjolfsson et al., 2008). Conversely, the ability to rapidly scale down operations - via divestitures of labour and capital - and the possibility to maximise salvage value is crucial to facilitate exit in the event of failure (Bartelsman et al., 2008). ${ }^{3}$ In this context, facilitating the expansion of successful innovative start-ups is particularly important for long-run growth. This is because firms that drive one technological wave often fail to continue to do so in the subsequent one, as they tend to concentrate on incremental improvements (Benner and Tushman, 2002), and young firms possess a comparative advantage in commercialising radical innovations (Henderson, 1993; Tushman and Anderson, 1986). ${ }^{4}$

Openness to trade is equally crucial because it fosters innovation via market size effects, tougher product market competition and larger knowledge flows. Larger market size stimulates investment in $\mathrm{KBC}$ by magnifying the expected profits in the event of successful ventures (Schmookler, 1966; Acemoglu and Lin, 2004). Globalisation implies that firms have to either differentiate their goods or lower their costs in order to stay competitive (see Section 4.1.2). It also promotes productivity-enhancing reallocation via the expansion of most productive firms into foreign markets and exit of low productivity firms that cannot compete in the global market or face the sunk cost to enter the foreign markets (Melitz, 2003; Melitz and Trefler, 2012). Finally, trade and foreign direct investment are associated with increased flows of knowledge from global customers and suppliers (Crespi et al, 2008) and from the activities of multinational firms.

\subsection{Misallocation and the role of policies}

In practice, frictions are likely to arise due to market failures related to knowledge and rigidities in factor markets. Investment in KBC is likely to be distorted by some specific features:

This is significant given that many successful entrepreneurs have experienced some form of business failure in the past (Choi, 2008).

4 The same is true for implementing innovations that appear relatively incremental from a technological point of view but require fundamental organisational restructuring (Henderson and Clark, 1990). 
- Private investment in KBC might be below the socially desirable level if the non-rival and only partially excludable nature of some forms of KBC means that firms cannot fully appropriate the returns from their investments, as some knowledge will "spill-over" to other firms.

- $\mathrm{KBC}$ is difficult to collateralise and its inherent riskiness reinforces traditional market failures in capital markets (e.g. information asymmetries), which may inhibit the implementation and commercialisation of new ideas, especially for KBC-intensive firms.

- The scale economies that arise from the non-rival nature of KBC can be reinforced by network externalities (i.e. the value of a product increases with the number of users), which in extreme cases lead to a winner-takes-all outcome. Network effects can lead to cases of natural monopoly or create high barriers to entry, limiting competition in areas where competitive pressures might raise efficiency.

These features are the source of (still unresolved) inefficiencies in knowledge markets, thus placing heightened importance on the efficient reallocation of tangible resources. Frictions in the reallocation of capital and labour are likely to lower the expected net benefits of innovative investment by making it more difficult for successful innovators to attract sufficient resources to underpin implementation and commercialisation of new ideas. And in the event that the innovative effort is unsuccessful, rigidities may make it more costly to downsize and exit from the failing venture, and allow entrepreneurs the space to experiment with new ideas. More broadly, barriers to entry in domestic and international markets will lower the supply of KBC directly, to the extent that new and young firms are an important source of new ideas, and indirectly by dampening competitive pressures on incumbents to generate $\mathrm{KBC}$ and by raising the cost and/or lowering the quality of inputs required by innovative firms to underpin their expansion.

The ease of reallocation influences firms' business strategies

At first glance, policies influence the different stages of the innovation process and productivity growth in a sequential fashion. However, firms' initial investments in KBC will likely be shaped by their perceptions of the expected costs of implementing and commercialising new ideas and the ability to capitalise on the expected benefits or to exit at low cost (which will both depend on the ease of reallocation). In particular, firms' innovation strategies will be influenced by their perceptions regarding the extent of rigidities in the reallocation process. If the costs of reallocation are deemed to be high, entrepreneurs may focus on incremental innovations, rather than experiment with disruptive technologies, because it will be more difficult to realise the benefits of risky technologies when successful and contain losses when unsuccessful (Bartelsman, 2004).

In turn, some entrepreneurs might decide to not even enter the market as it might not be profitable nor sustainable to enter with just an incremental innovation (Shane, 2001; Bhide, 2000). Hence, the extent of specialisation in sectors that rely more on reallocation - such as more innovative or ICT-intensive sectors - may vary across countries (Bartelsman et al., 2010), partly as a result of how different policy settings influence the nature of resource flows across incumbents and new entrants and thus the scale of production in these sectors.

\subsection{Side effects of the knowledge-based economy}

The gearing of public policy to maximise the growth potential of KBC may not have unambiguously positive effects, and trade-offs may emerge with other policy goals. First, some forms of KBC may carry undesirable side effects: expenditures on marketing and intellectual property rights (see Section 4.2.4) may be undertaken to create significant upfront costs to deter firm entry while rent seeking behaviour is also an intangible investment from the firm's perspective (Hunter et al., 2005). Second, while efficient reallocation raises the returns to $\mathrm{KBC}$, the shifting of resources entails costs for firms, workers and governments and thus excessive reallocation is no more desirable than the 
persistent trapping of resources in inefficient activities. Third, there may be a tension between policies that promote experimentation and raise the returns to innovation and equity concerns.

The KB economy - by definition - rewards high skills. This is likely to reinforce rising income inequality via skill-biased technological change, whereby technological progress has substituted for routine and medium-level tasks, thereby displacing workers, while increasing the value of other "new economy" tasks (Autor et al., 1998). One aspect of this has been the tendency for firms to introduce information technologies against a backdrop of fundamental organisational restructuring- made possible by KBC (see Section 3.1) - which has changed the mix of skills that firms require towards performing non-routine tasks (e.g. organisational and management tasks; see Bresnahan et al., 2002).

Rising investment in $\mathrm{KBC}$ also entails technologies that can create winner-takes-all opportunities for a tiny few (Brynjolfsson and McAfee, 2011). Digital technologies - which allow the replication of informational goods and business processes at near zero marginal cost - enables the top-quality provider to capture most, or all, of their market, while only a tiny fraction of that revenue may accrue to the next-best (even if they are almost as good as the best provider). Besides generating disproportionately strong income growth at the very top end of the income distribution, such outcomes may undermine work incentives by detaching effort from reward and carrying concerns from a competition policy perspective (see Section 2.2).

\section{Investment in $\mathrm{KBC}$, reallocation and productivity growth}

\subsection{The links with aggregate growth}

Wide and persistent differences in the level of MFP account for the bulk of income per capita gaps across countries (Figure 2, Panel A; Easterly and Levine, 2001)..$^{5}$ Similarly, those countries that have succeeded in converging towards high-income countries over recent years have often done so on the back of a convergence in MFP and the stock of knowledge (Figure 2, Panel B). In theory, MFP reflects the efficiency with which inputs are used, via improvements in the management of production processes, organisational change or $R \& D$ and innovation more generally. Thus, it is natural to examine the link between these gaps in MFP growth and cross-country differences in investment in KBC which - as discussed below - tend to be significant.

Indeed, once estimated KBC is incorporated into growth accounting, the contribution of MFP growth to labour productivity growth tends to fall. ${ }^{6}$ Over the period $1995-2006$, incorporating KBC is estimated to reduce the contribution of MFP by close to one-half in Sweden; one-quarter in the United States and Finland; roughly one-fifth in France, the United Kingdom, Czech Republic and Australia; and by one-tenth or less in Austria, Denmark, Germany and Japan (van Ark et al., 2009; OECD 2011a).

MFP growth relates a change in output to changes in several types of inputs. MFP is often measured residually, as that change in output that cannot be accounted for by the change in combined inputs.

6 For specific details on how KBC investment figures are estimated and underlying assumptions, see Corrado et al., (2012). 


\section{Figure 2. Multi-factor productivity drives cross-country differences in GDP per capita}

A: Contribution of production factors to GDP per capita (relative to the United States in 2011)

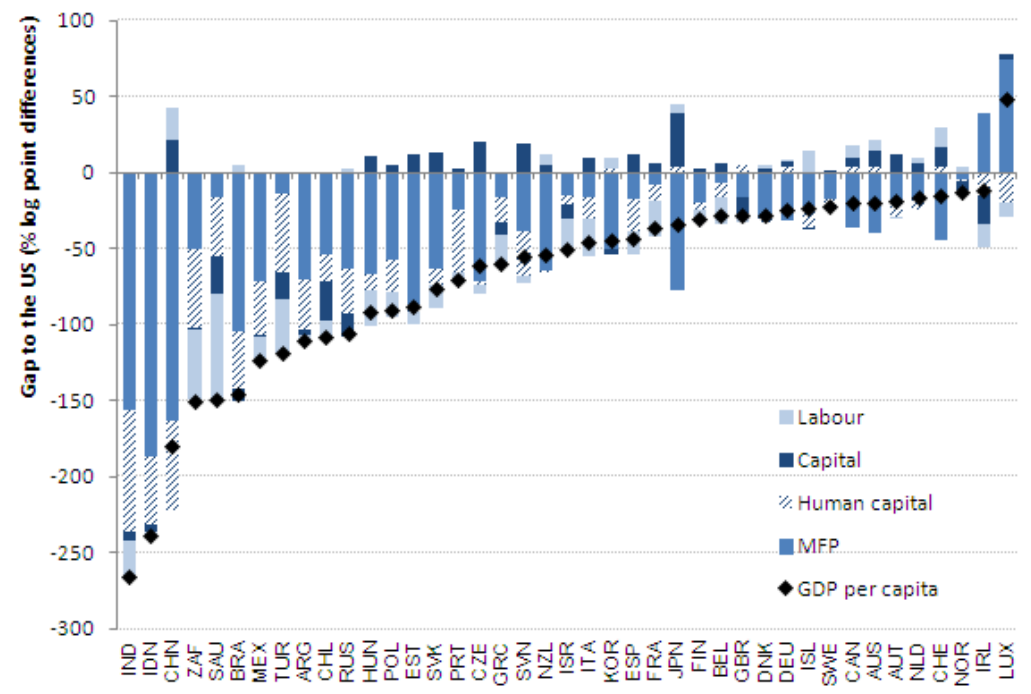

B: Contribution to growth (2000-2011)

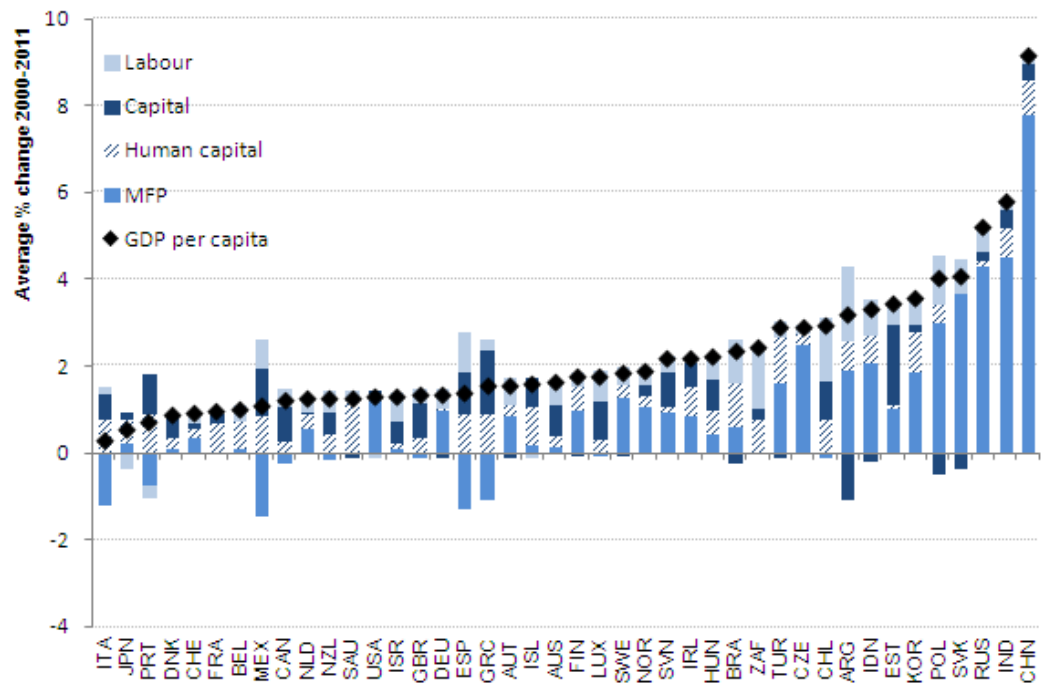

StatLink ज्ञाI SR http://dx.doi.org/10.1787/888932824726

Source: Johansson et al., (2012).

As discussed below, important differences across countries exist in the contributions of MFP and KBC deepening to GDP growth. This reflects both differences in the amount of investment in intangible assets and differences in the returns (i.e. marginal product) to these investments. ${ }^{7}$ For example, there are persistent differences in the intensity of business R\&D and patenting across countries that remain after controlling for differences in industrial structure, suggesting that such

This assumes that the estimated factor share reflects the marginal product of KBC. 
variation in the use of $\mathrm{KBC}$ cannot solely be explained by structural differences such as trade specialisation patterns (Figure 3). ${ }^{8}$ These differences are also important given that business R\&D intensity and patenting have been closely linked to productivity performance (Bloom and Van Reenen, 2002; Hall et al., 2010; Westmore, 2013), and for economies far from the technology frontier, $\mathrm{R} \& \mathrm{D}$ is still necessary to facilitate the adoption of foreign technologies (Griffith et al., 2004).

\section{Figure 3. Business R\&D, Patenting and MFP performance}

A: Business R\&D to GDP and Patents per capita
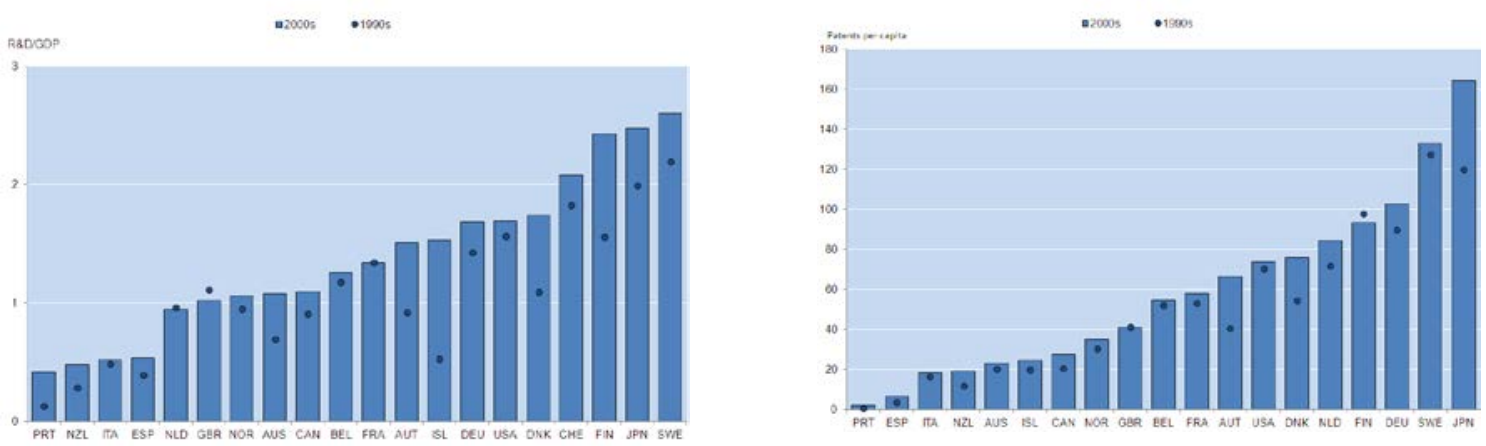

B: MFP growth and Business R\&D intensity; 1986 - 2008

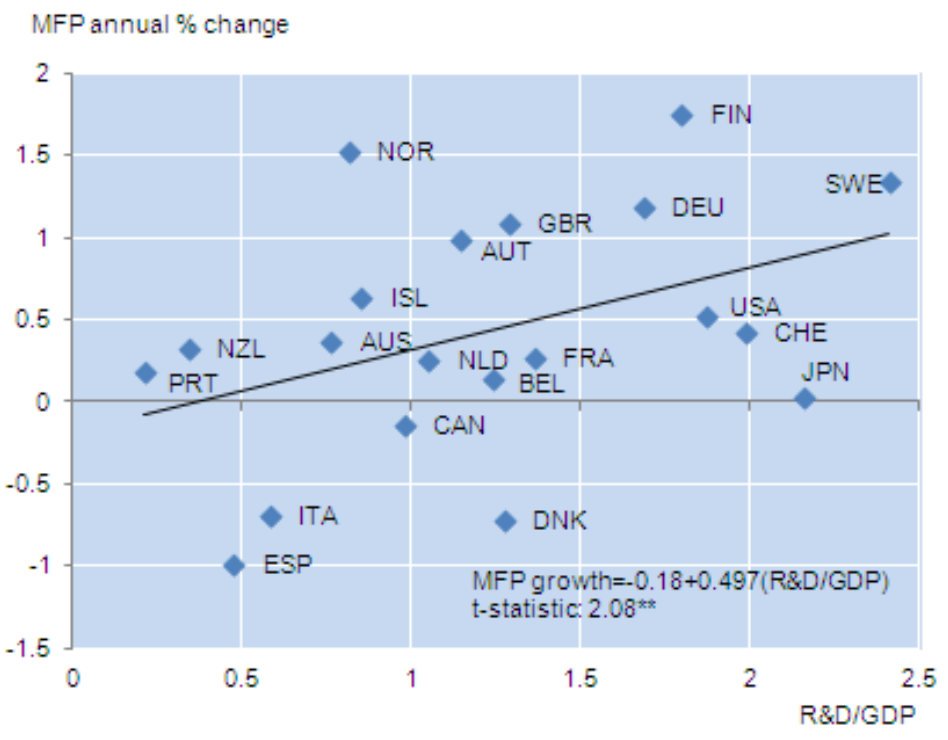

StatLink जinst http://dx.doi.org/10.1787/888932824745

Notes: The patent measure is based on triadic patents, which refer to a series of patents for the one invention filed at the European Patent Office, the United States Patent and Trademark Office and the Japan Patent Office.

Source: OECD (2011a), OECD Productivity Database and OECD calculations, based on Johansson et al., (2012). See Westmore (2013) for more details.

8 For example, in a sample of 26 OECD countries in 2008, the rank correlation between headline Business R\&D (BERD) Intensity and BERD adjusted for differences in industrial structure is around 0.80 (see OECD 2011a for details). 
At the same time, estimates of managerial quality - based on interviews of middle management from randomly drawn samples of firms - vary widely across OECD countries (Figure 4) and recent research uncovers a causal effect of managerial quality on firm productivity (Bloom et al., 2013a). For example, raising managerial quality from the median level (roughly corresponding to New Zealand in Figure 4) to the high level in the United States could increase the average level of productivity in manufacturing by as much as 10\% (Bloom et al., 2012a).

\section{Figure 4. Managerial quality differs across countries with important implications for productivity}

Average management quality score in the manufacturing sector; selected countries
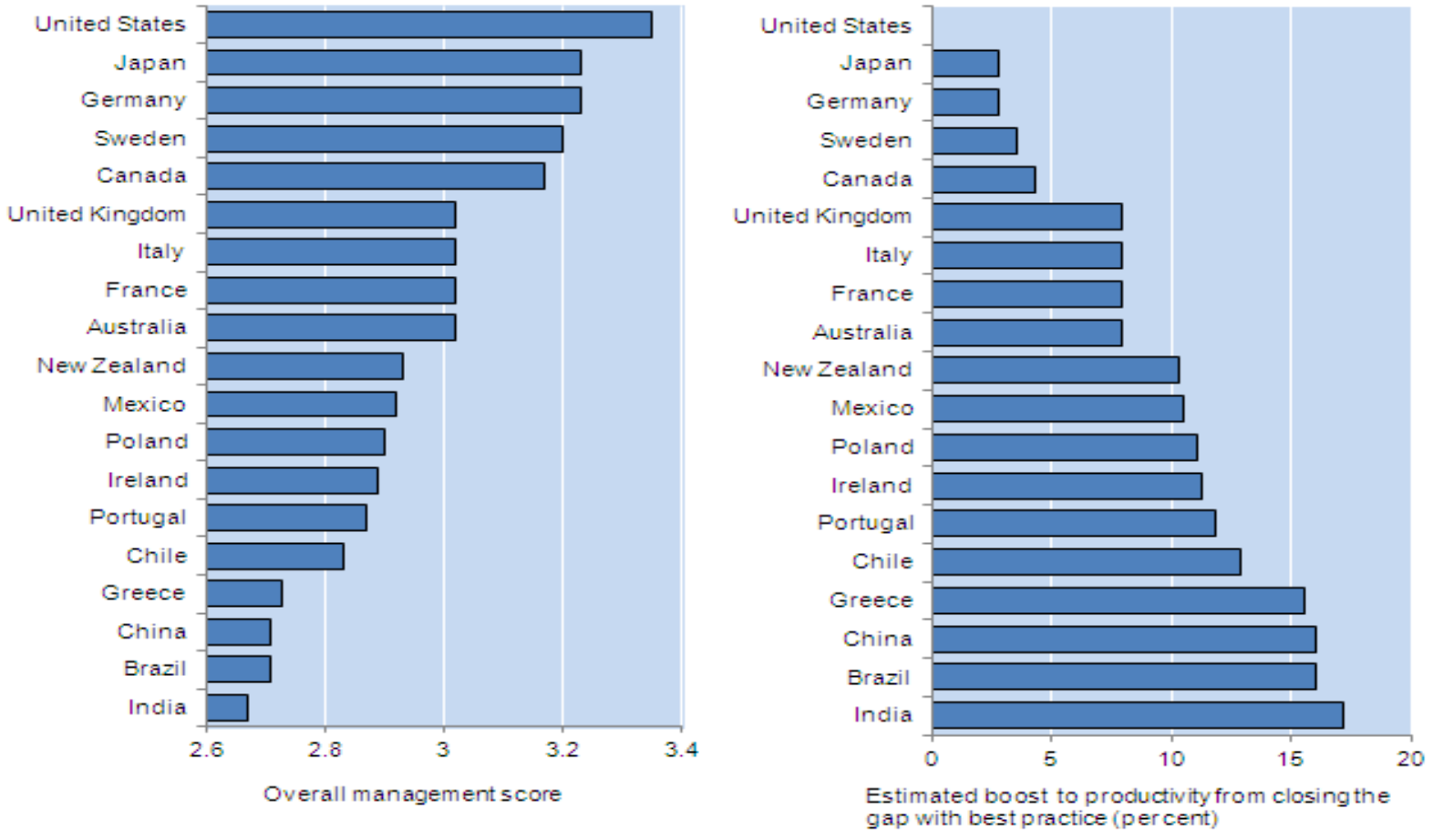

StatLink *ins http://dx.doi.org/10.1787/888932824764

Notes: The overall management score is an average of responses to 18 survey questions that are designed to reveal the extent to which firms: i) monitor what goes on inside the firm and use this information for continuous improvement ii) set targets and track outcomes; and (iii) effectively utilise incentive structures (e.g. promote and rewarding employees based on performance). The estimates in the right panel are calculated from the difference in management score between each country and the United States and the estimated coefficient on the management score term in a firm level regression of sales on management scores, capital and employment. The sample is based on medium-sized firms, ranging from 50 to 10000 employees.

Source: OECD calculations based on the management scores and estimated coefficients in Bloom et al., (2012a).

These cross-country differences in $R \& D$, patents and managerial quality are reflected in broader estimates of $\mathrm{KBC}$, which also include computerised information, creative property, design, brand equity and firm specific human capital (Figure 5). ${ }^{9}$ For example, English-speaking countries particularly the United States - Japan and Sweden, invest relatively heavily in KBC which translates into a relatively larger contribution of intangible capital deepening to labour productivity growth

These estimates have been constructed using a variety of sources and techniques, and requires assumptions about depreciation rates and deflators. However, the approach is standardised to facilitate cross-country comparisons. For more details, see Corrado et al., (2012) 
(Figure 6). By contrast, the resources devoted to KBC and their contribution to productivity growth tend to be smaller in some continental and Southern European economies (van Ark et al., 2008).

\section{Figure 5. Investment in KBC varies significantly across countries}

Panel A: Per cent of GDP; Selected OECD countries, 2009 or latest data available

- Innovative Property a Software aEconomic Competencies

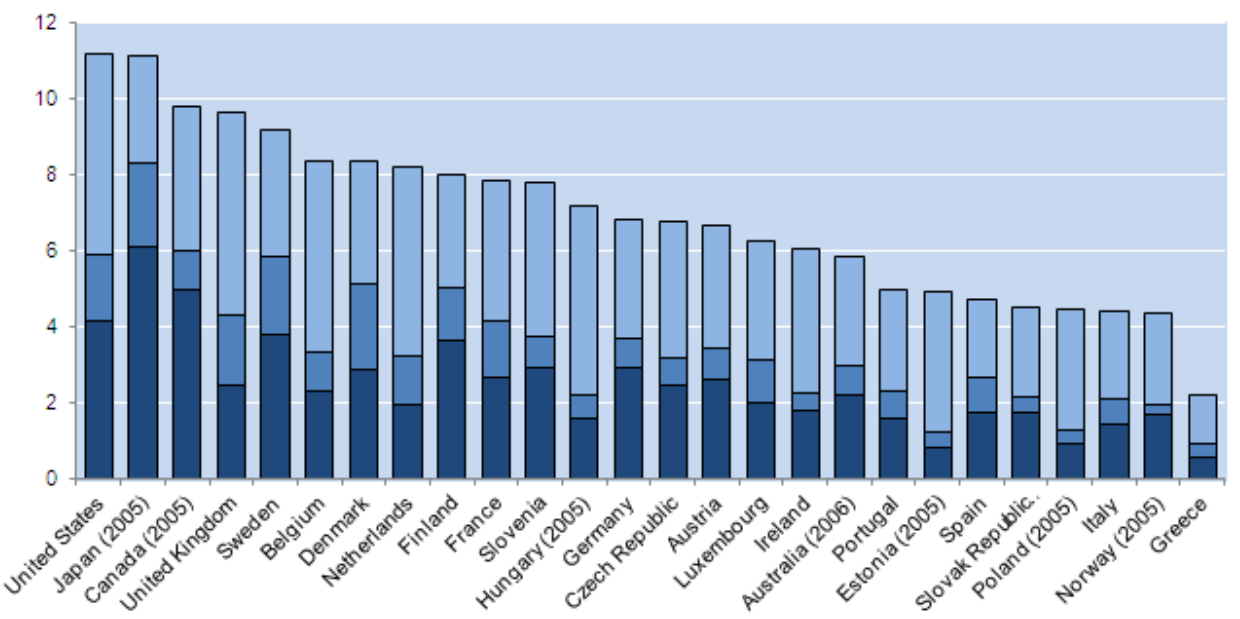

Panel B: The evolution of investment in KBC relative to tangible capital; 1995-2009 (unless otherwise noted)

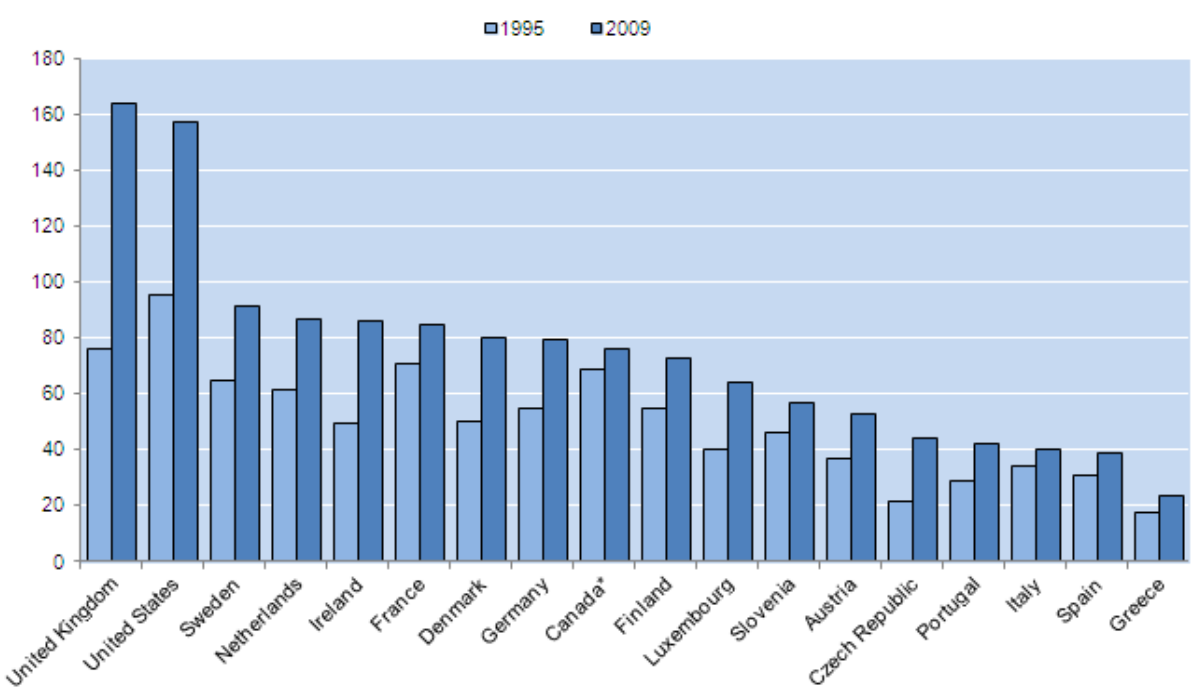

StatLink ज्ञात http://dx.doi.org/10.1787/888932824783

Notes: The estimates refer to the market sector and include each of the types of KBC outlined in Table 1 and mineral exploration. *Data for Canada in Panel B refer to 1998 and 2005.

Source: Corrado et al., (2012).

Beyond their direct effect on capital accumulation, these cross-country differences matter to the extent that KBC is often only partially excludable, which implies that privately created knowledge diffuses beyond its place of creation, thus providing wider benefits. While estimating knowledge spillovers is challenging, empirical studies which focus on R\&D have generally found these effects to 
be relatively large (Hall et al., 2010; Australian Productivity Commission, 2007). Furthermore, a positive association between the contribution of capital deepening and MFP growth is clearer for KBC than for tangible capital, which provides suggestive - albeit crude - evidence of such spillover effects (Figure 6). .

Figure 6. Knowledge-based capital and spillover effects

\section{Selected OECD Countries; 1995-2007}
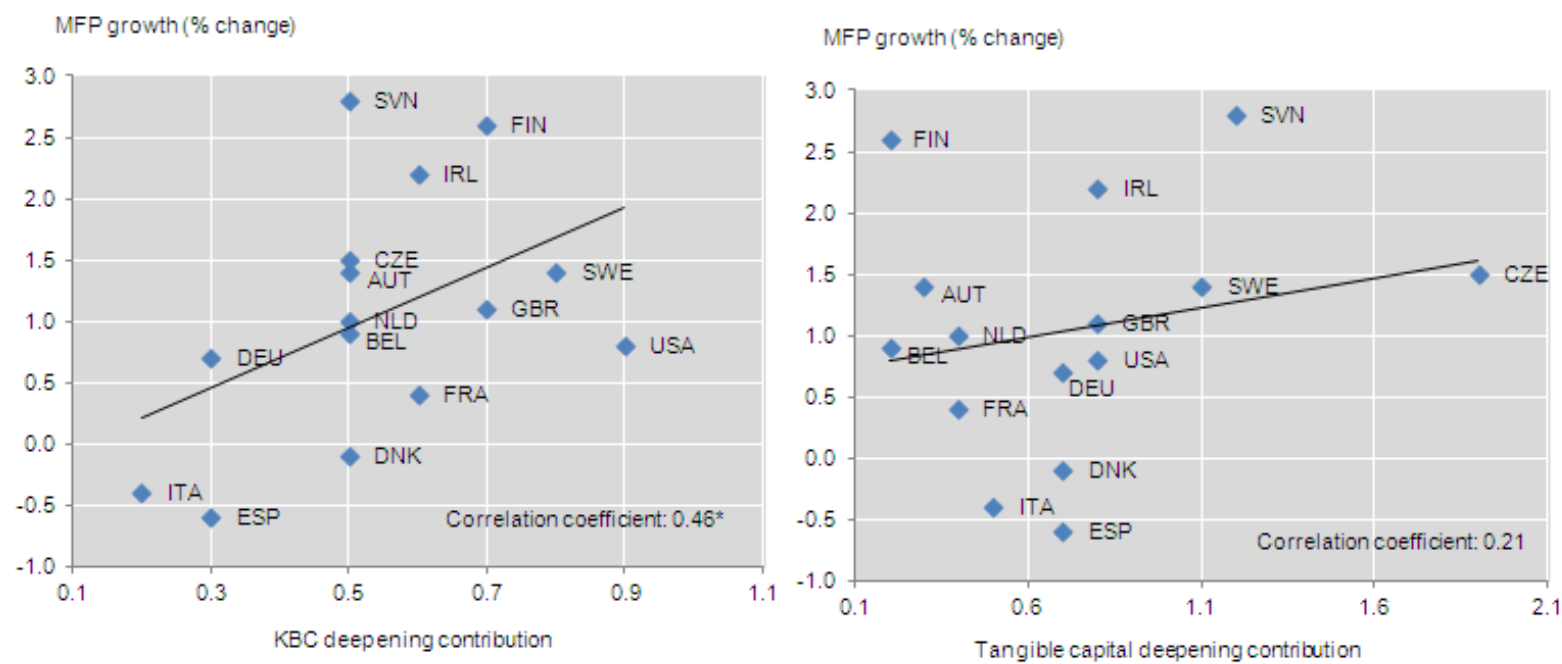

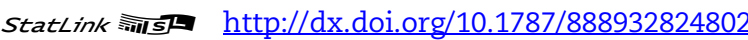

Note: Labour productivity growth can be decomposed into the contribution of capital deepening and the contribution of MFP. The chart plots the contribution of $\mathrm{KBC}$ /tangible capital deepening to labour productivity growth against the growth rate in MFP. The correlations are robust to individually dropping outliers, such as the Czech Republic, Finland and Slovenia. Unlike in conventional growth accounting exercises (e.g. Figure 2), the MFP estimates are based on a value-added series that capitalises the full set of KBC indicators outlined in Table 1. * denotes statistical significance at the $10 \%$ level.

Source: Corrado et al., (2012).

There are also important complementarities between organisational capital and ICT capital investment, which are particularly significant to the extent that cross-country differences in aggregate growth in OECD countries depend to a large extent on the performance of key ICT-intensive sectors (van Ark et al., 2008). In order to extract the maximum benefit from ICT, firms typically need to adopt ICT as part of a "system" of mutually reinforcing organisational changes (Brynjolfsson et al., 1997), which will be easier to accommodate in firms with better organisational capital. Indeed, Bloom et al., (2012b) attributed at least one half of the US-"Europe" ${ }^{10}$ difference in labour productivity growth between 1995 and 2004 to superior management practices, which significantly raised the productivity of ICT capital in the United States.

\subsection{From macro to micro: KBC innovation and resource allocation}

\subsubsection{Differences in resource allocation are correlated with KBC use}

Cross-country differences in $\mathrm{KBC}$-deepening at the aggregate level tend to coincide with diverging patterns of firm performance within countries, which reflect the scope and ease of reallocation and prevalence of certain innovation strategies. Empirical evidence suggests that some

${ }_{10}$ In this study, Europe includes the following seven countries: France, Germany, Italy, Poland, Portugal, Sweden, and the United Kingdom 
countries are more successful than others in channelling resources towards innovative and high productivity firms. One consequence of this is that the extent to which, ceteris paribus, it is the most productive firms that hold the largest market shares - a metric that has been taken to represent the degree of allocative efficiency in an economy (Olley and Pakes, 1996) - also tends to vary across countries. For instance, new OECD estimates suggest that more productive firms are likely to account for a much larger share of manufacturing employment in the United States and some Nordic countries than in some Continental and Southern European countries (see Figure 7). Moreover, an emerging literature links these sizeable differences in allocative efficiency across countries to policy distortions, which carry important consequences for aggregate performance. For example, estimates suggest that if China and India were able to align their efficiency of resource allocation to that observed in the United States, manufacturing TFP could rise by $30-50 \%$ in China and $40-60 \%$ in India (Hsieh and Klenow, 2009).

\section{Figure 7. Contribution of allocation of employment across firms to manufacturing labour productivity}

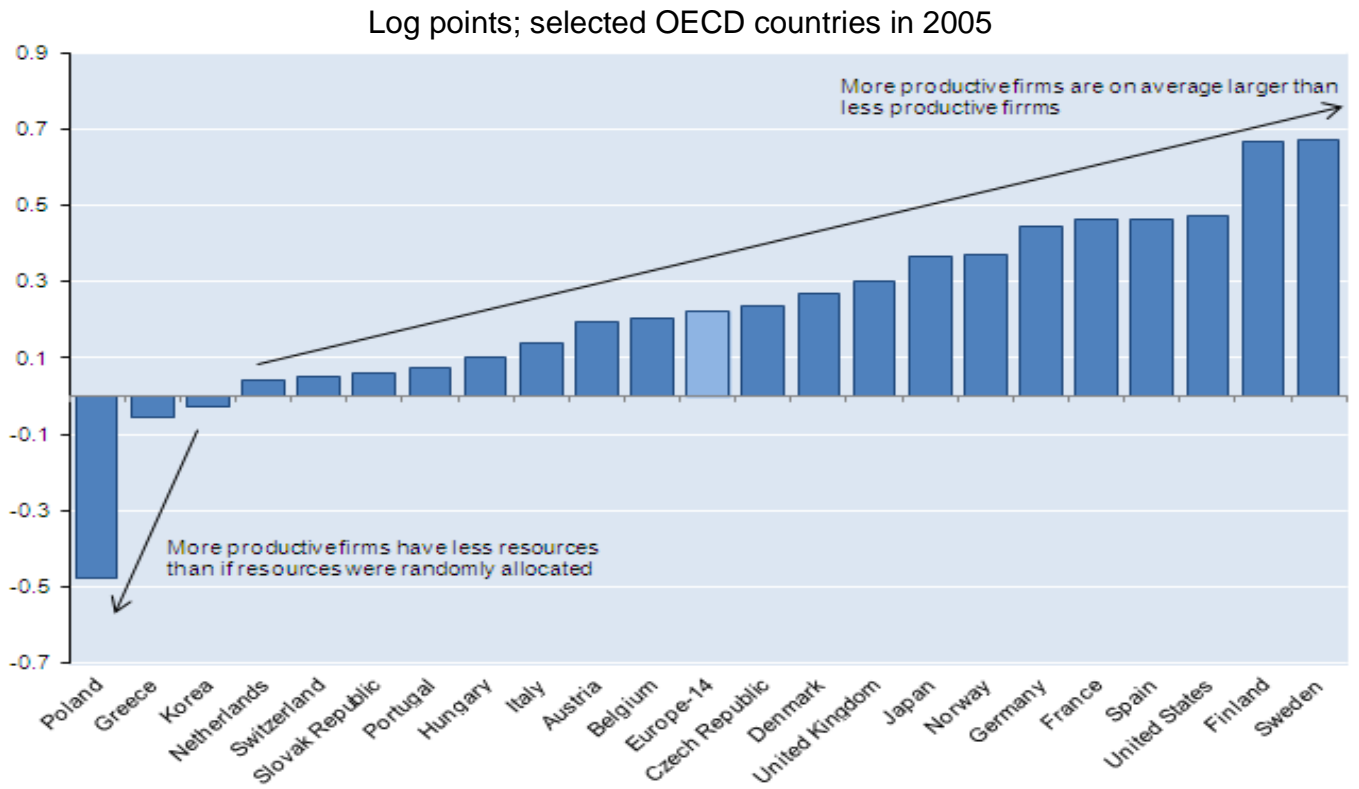

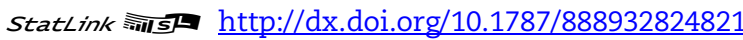

Notes: the estimates show the extent to which the firms with higher than average labour productivity have larger employment shares. In most countries, the covariance between productivity and employment share is positive, suggesting that the actual allocation of employment boosts manufacturing labour productivity, compared to a situation where resources were allocated randomly across firms (this metric would equal zero if labour was allocated randomly). For example, manufacturing labour productivity in the United States is boosted by around $50 \%$ due to the rational allocation of resources. Europe-14 includes: Austria, Belgium, Czech Republic, France, Greece, Germany, Hungary, Italy, Netherlands, Portugal, Poland, Spain, Slovak Republic and Switzerland, and is obtained by aggregating the respective allocative efficiency indicators by each countries share in manufacturing sector employment.

Source: OECD calculations based on firm level data from the ORBIS Database. See Andrews and Cingano (2012).

Countries that are more successful at channelling resources to the most productive firms also tend to invest more in KBC. As argued in Section 2, incentives to invest in KBC partly depend on perceptions about the ease with which labour and capital will flow to successful firms (i.e. can be reallocated from less productive to more productive firms), which would ultimately result in a more efficient allocation of resources in an economy. Figure 8 provides prima facie evidence of a positive correlation between investment in $\mathrm{KBC}$ and the efficiency of allocation, based on the indicator 
introduced in Figure $7 .{ }^{11}$ This evidence is confirmed by a range of more formal empirical analyses reported below.

Figure 8. Knowledge-based capital deepening and efficiency of resource allocation

\section{Selected OECD countries}

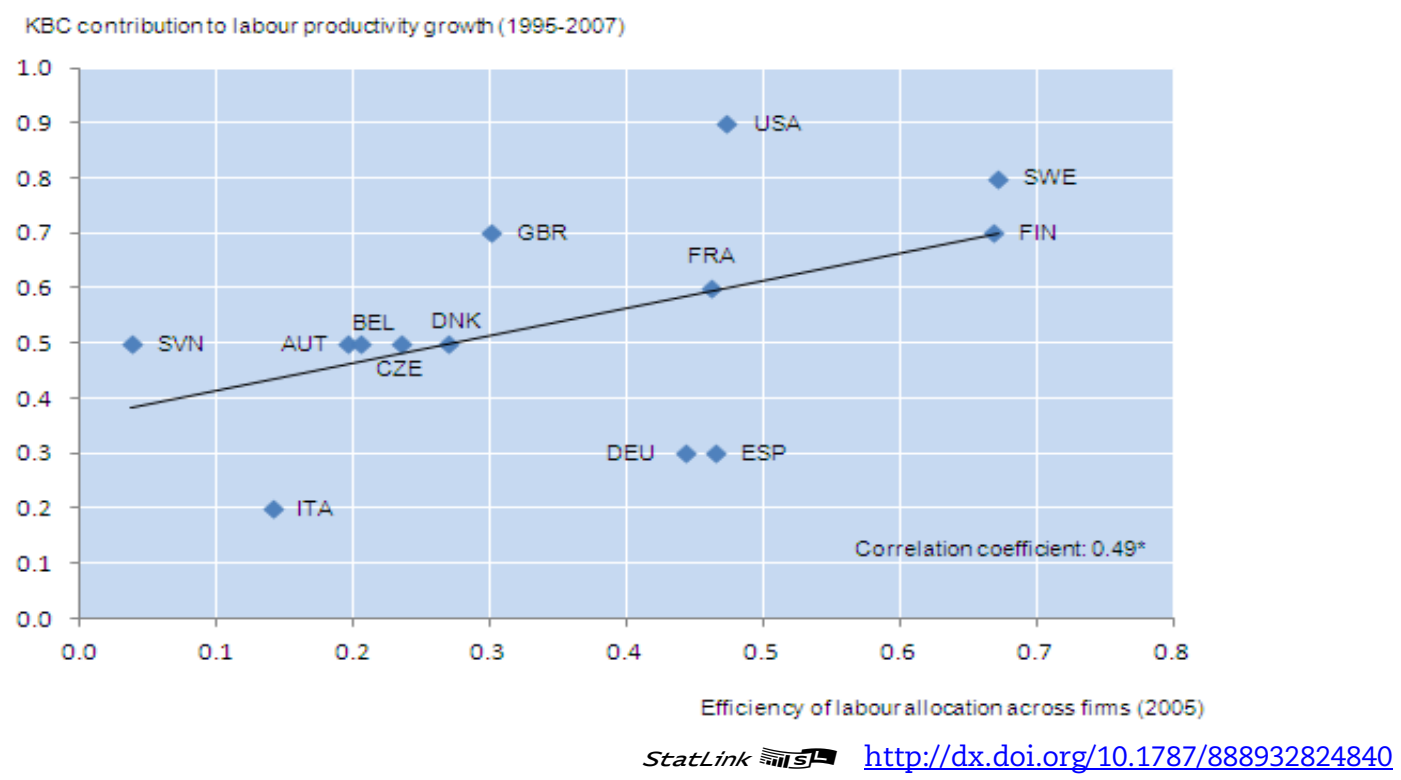

Source: Details on the intangible capital and resource allocation estimates are contained in Figures 6 and 7 respectively.

\subsubsection{The extent to which innovative firms can attract resources differs across countries}

Cross-country differences in the post-entry performance of firms tend to be more marked than differences in entry and exit patterns (Bartelsman et al., 2003). Indeed, there are large differences across countries in the extent to which young firms grow over their life-cycle (Hsieh and Klenow, 2012). For example, from birth to age 35 years, employment at the typical (surviving) manufacturing plant increases by a factor of 10 in the United States, two in Mexico and actually declines in India, while productivity increases by a factor of eight in the United States, but only by two in India and Mexico.

Firm-level empirical studies also reveal important differences between higher income countries. The size of entering and exiting firms tends to be smaller in the United States than in Europe and successful young firms tend to expand relatively more quickly in the United States than elsewhere (Bartelsman et al., 2012). This is consistent with a more dynamic distribution of firm growth in the United States, whereby successful firms grow faster and unsuccessful firms shrink faster, than in Europe (Figure 9). The levels and growth rate of firm productivity within industries also tend to be more dispersed in the United States than in Europe (Bartelsman et al., 2004), though more recent evidence points to important differences in productivity dispersion across countries in Europe (Altomonte, 2010). These differences between the United States and "Europe" ${ }^{12}$ might reflect a greater

${ }_{11}$ The extent to which the most productive firms are also the largest at any point in time will reflect the extent to which resources are reallocated away from less productive to more productive uses over preceding time periods.

12 See notes to Figure 9 for countries included. 
degree of experimentation and "learning by doing" among entrants in the United States, given that the largest differences can be found in high technology and emerging sectors, where the imperative for experimentation and intensity in the use of KBC is likely to be greatest (Bartelsman et al., 2008). This suggests that differences in institutional factors, which shape differences in the cost of reallocating resources, may explain the relative sluggishness of some European countries to capitalise on the ICT revolution (Bartelsman et al., 2010; Conway et al., 2006), and the growth potential embodied in $\mathrm{KBC} .^{13}$

\section{Figure 9. The distribution of firm employment growth}

United States and selected European countries; 2002-2005
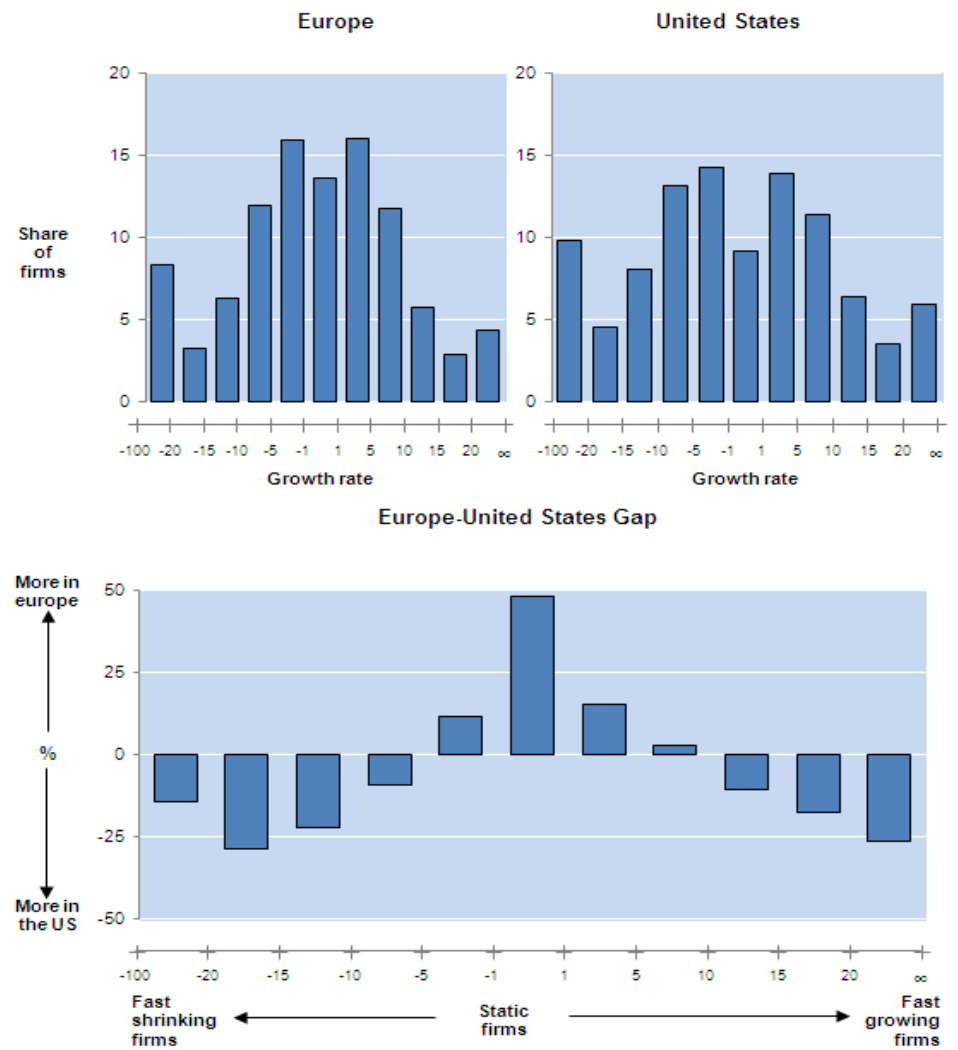

StatLink *ins http://dx.doi.org/10.1787/888932824859

Notes: The chart compares the distribution of firm employment growth between the United States and the average of seven European countries selected on the basis of data availability (e.g. Austria, Denmark, Spain, Finland, Italy, Netherlands and Norway). The European countries included in the sample have a larger share of static firms (those growing between -5 and $5 \%$ a year) relative to the United States, where firms that grow more than $5 \%$ or shrink more than $5 \%$ a year are more prevalent. The bottom panel of the chart shows the Europe-US differential in percentage terms. For example, the share of firms with employment growth above $20 \%$ is $5.9 \%$ in the United States and $4.3 \%$ in Europe, which translates into a differential of around $26 \%$. Europe corresponds to the average of:

Source: Bravo-Biosca (2010) based on national business register data.

To effectively implement and commercialise new ideas, firms require a range of complementary tangible resources to test ideas (e.g. to develop prototypes and business models),

13 Cross-country differences in firm growth trajectories could also reflect differences across countries in the extent to which young firms get absorbed by larger incumbent firms. Unfortunately, evidence on this issue is scarce. 
develop marketing strategies and eventually produce at a commercially viable scale (Figure 1). New OECD evidence (Andrews et al., 2013) - which uses longitudinal data to explore what happens to important economic variables when firms patent - reveals important differences across countries in the extent to which capital and labour flow to innovative firms. For example, a $10 \%$ increase in the patent stock is associated with an increase in the typical firm's capital stock of about $3 \%$ in Sweden and the United States; $1 \frac{1}{2} \%$ in the United Kingdom and Germany; and a $1 / 2 \%$ in Italy and Spain (Figure 10; Panel A). Similarly, the ease with which patenting firms in the United States can attract labour is roughly twice as large as the average OECD country (Figure 10; Panel B). ${ }^{14}$

Figure 10. Do resources flow to more innovative firms?

Additional inputs attracted by a firm that increases its patent stock by $10 \% ; 2002-2010$

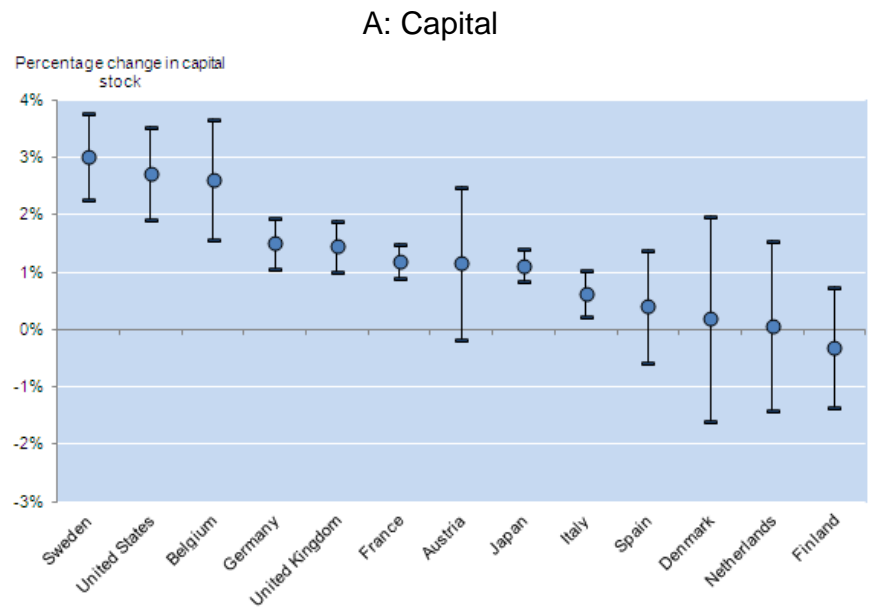

B. Employment

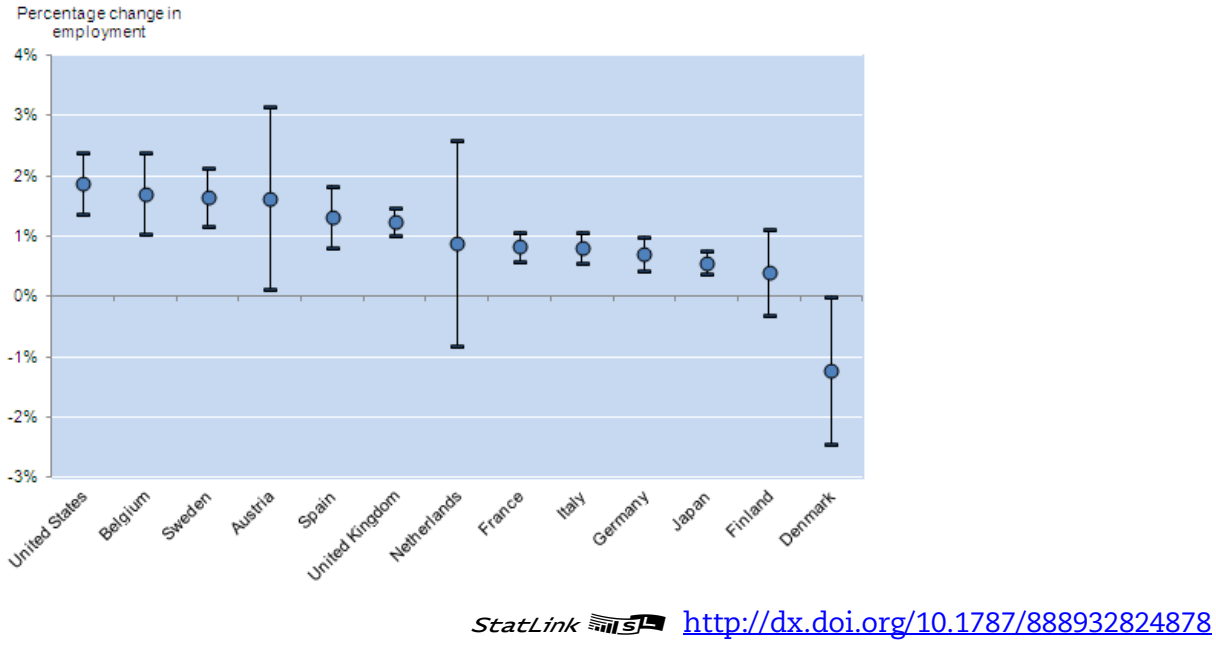

14 The low sensitivity of resources to patenting in countries such as Denmark and Finland may reflect the fact that firms in small open economies may expand abroad rather than domestically, but it is difficult to capture this margin of adjustment with the available data. Additional analysis suggests that patenting has a larger effect on average profitability and wages than firm size in these countries, but this cannot explain all of the observed difference. 
Notes: The black dot shows the country-specific point estimate while the grey bands denote the $90 \%$ confidence interval (note that the confidence intervals vary across countries due to differences in the number of observations). These estimates are obtained from the following baseline fixed effects regression specification:

$$
\ln Y_{i, s, c, t}=\beta_{1} \ln \left(P_{a t} S_{i, s, c, t}\right)+\eta_{i}+\mu_{s, c, t}+\varepsilon_{i, s, c, t}
$$

Where: $\mathrm{Y}$ is the economic characteristic (employment or capital) for firm $\mathrm{i}$, in sector $\mathrm{s}$, in country $\mathrm{c}$ at time $\mathrm{t}$ and PatS is the depreciated patent stock of firm i. The specification also includes firm fixed effects and industry*country*year fixed effects. To obtain the country-specific estimate, PatS is interacted with various dummy variables for each country.

Source: OECD calculations based on firm level data from the ORBIS-Patstat Database for the non-farm business sector. See Andrews et al., (2013).

These cross-country differences tend to be driven by younger firms: the sensitivity of capital with respect to patenting is about five times as large in the United States as compared with Italy for young firms, but this differential is only about double amongst older firms. Caution should be used when drawing conclusions from these cross-country differences given the limitations of the data. However, their significance is enhanced by the fact that the extent to which young firms patent varies considerably across countries and that, while young firms account for a smaller number of patents, they are significantly more likely to file a radical patent than older firms (Andrews et al., 2013). Moreover, the resource flows associated with radical patents are around two times larger in Sweden and the United Kingdom relative to Italy. One interpretation of these findings is that in countries where reallocation costs are lower, firms may be more willing to experiment with disruptive technologies than in environments where reallocation costs are higher.

\section{The role of public policy}

While a wide range of policy instruments can potentially influence the KBC-innovationreallocation nexus, this section focuses on a key subset of policies affecting the business environment and innovation using the framework developed in Section 2. For each policy instrument, the paper explores the direct and indirect impact of the policies on the three building blocks - (1) developing and adopting new ideas; (2) implementing and commercialising new ideas; and (3) reaping the benefits of new ideas through changes in market share and profitability. For illustrative purposes, Figure 11 shows some preliminary evidence on the links between selected public policies and investment in KBC sourced from a recent study by Corrado et al., (2012). While these correlations are only suggestive (and subject to reverse causality), countries with less stringent regulations in product and labour markets and deeper financial markets tend to be characterised by higher rates of investment in $\mathrm{KBC}$, while investment in $\mathrm{KBC}$ is also positively correlated with debtor-friendly bankruptcy codes and higher seed and early stage venture capital. 


\section{Figure 11. Investment in KBC and selected public policies}

Share of GDP; selected OECD countries, 2005

Product market regulations restricting competition

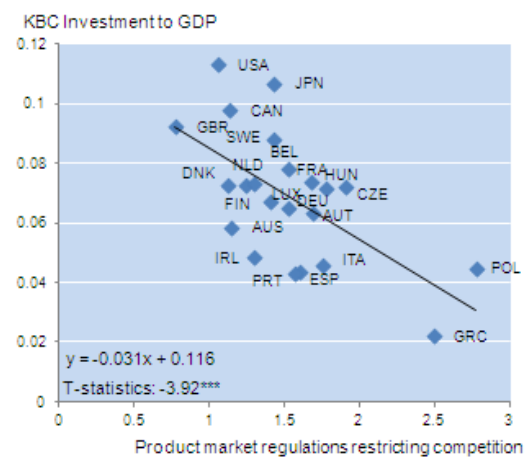

Private Credit to GDP

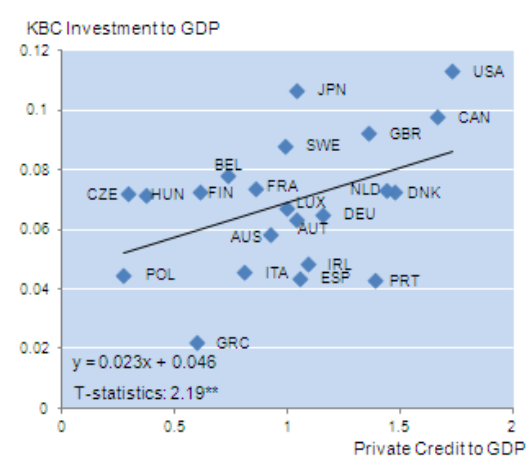

Creditor friendliness of bankruptcy law

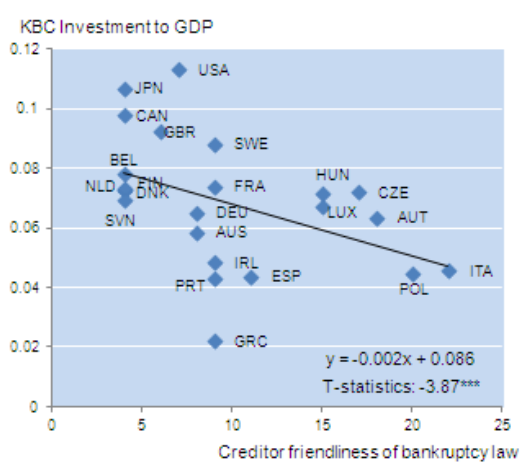

Strength of patent rights

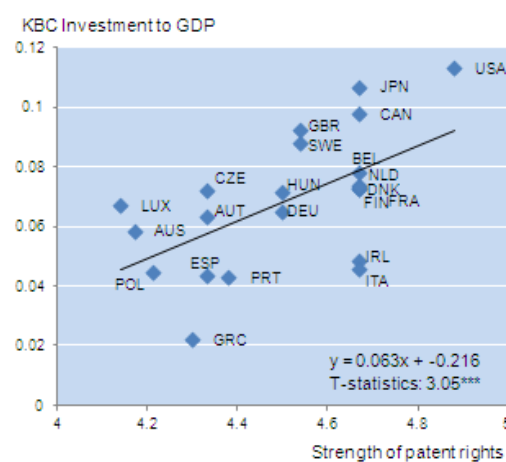

StatLink 게느
Stringency of job protection legislation

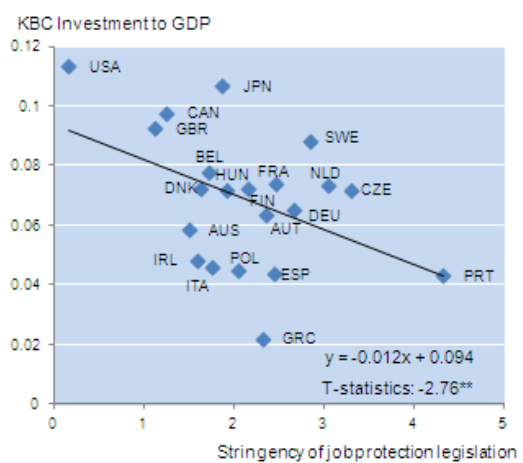

Investment in early stage VC

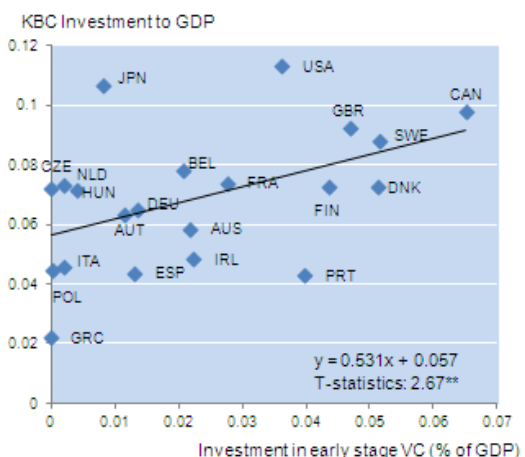

http://dx.doi.org/10.1787/888932824897

Notes: Investment in KBC to GDP is measured in 2005, while the policy indicators refer to either 2003 (PMR, EPL, Bankruptcy Law and Private Credit to GDP) or 2005 (Patent rights and early stage VC). Bankruptcy Law is proxied by the cost to close a business.

Source: OECD calculation based on intangible capital estimates from Corrado et al., (2012), and policy indicators from: the OECD (PMR, EPL and Early Stage VC), World Bank (Bankruptcy Law and Private Credit to GDP) and Park (2008; Patent Rights).

\subsection{Framework policies have pervasive impacts on the KBC innovation-reallocation nexus}

\subsubsection{Product market regulations}

Product market regulations (PMR) have a pervasive impact at each stage of the innovation process, as suggested in empirical studies that show a negative relationship between PMR and productivity at the aggregate level (Bouis et al., 2011) and the firm and sectoral levels (Aghion et al., 2004; Bourles et al., 2010) and an inverted U-shaped relationship between indicators of competition and innovation (Aghion et al., 2005).

PMR shape the formation of new ideas (i.e. Stage 1 of Figure 1) via their effects on innovative effort. Lower entry regulations increase the supply of new ideas by raising firm entry rates (Fisman and Sarria-Allende, 2010; Klapper et al., 2006; Ciccone and Papaioannou, 2007), which in turn increase the pressure on incumbent firms to innovate via heightened competitive pressure. New OECD 
evidence shows that a modest reduction in PMR in the energy, transport and communications sectors - corresponding to the difference in regulation between Australia and Austria in 2008 - could result in a $5 \%$ increase in the stock of business enterprise R\&D and a $3 \%$ rise in patents per capita in the long run (Westmore, 2013). This could be expected to raise annual MFP growth by around $0.1 \%$ but the effects would take some time to materialise given the relatively sluggish adjustment of R\&D to shocks. Similarly, the positive impact of knowledge spillovers from abroad on domestic patenting activity is significantly higher in countries where barriers to entry for new firms are relatively low (Westmore, 2013), suggesting that reforms to PMR can also raise the incentives for firms to incorporate foreign technologies (Parente and Prescott, 2000; Holmes et al., 2008).

One of the channels through which product market reforms affect innovation and its implementation is via improved managerial performance, which could enhance the ability of firms to undertake the internal reallocations required to implement new technologies and to sustain the innovation process. Pro-competition policies are likely to improve management performance by imposing greater market discipline, which truncates the left tail of poorly managed (and unproductive) firms (Schmitz, 2005; Bloom and Van Reenen, 2010). Consistent with this, the tail of poorly managed firms in countries where product market regulations are less stringent - particularly, the United States - is smaller than in other countries where product market regulations are, on average, more cumbersome (Figure 12).

\section{Figure 12. Product market regulations restricting competition and the distribution of managerial practices across firms}

Increasing in efficiency; manufacturing firms in selected countries, 2004-2010

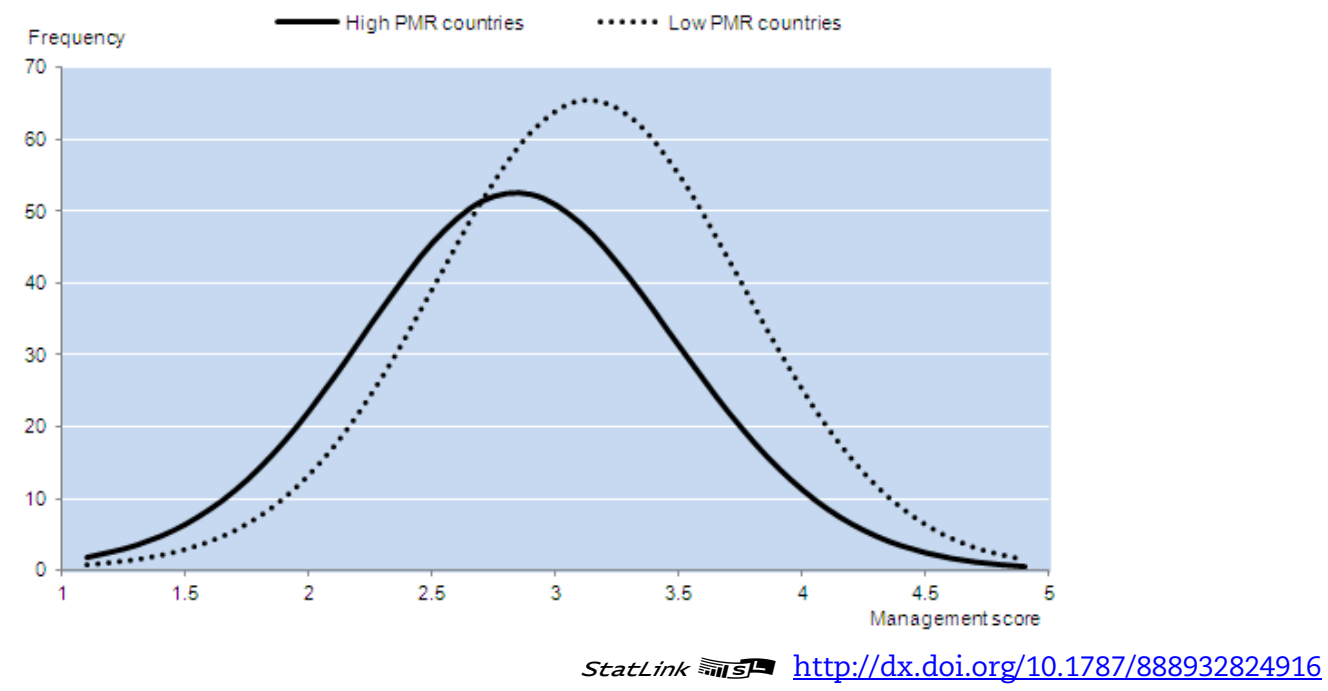

Notes: Countries are grouped according to their ranking in the overall OECD product market regulation index in 2008. Countries in the low PMR group include: Australia, Canada, Germany, Japan, New Zealand, Ireland, Sweden, United Kingdom and the United States. Countries in the high PMR group include: Brazil, Chile, China, France, Greece, India, Italy, Mexico, Poland and Portugal. Since the number of firms in the underlying dataset varies across countries, the management score distributions are scaled to a common number of firms in each country prior to aggregation. See Figure 4 for details on management score data.

Source: OECD calculations based on management score data sourced from Bloom et al., (2012a) and OECD PMR indicators.

Product market regulations also influence innovation through the ability of successful firms to attract the complementary tangible resources that are required to implement and commercialise new ideas (i.e. Stage 2 of Figure 1). Figure 13 shows how the estimated flow of resources to patenting firms - a concept first introduced in Figure 10 - varies with different public policy settings, based on new 
OECD econometric modelling (see Andrews et al., 2013). For example, a policy reform that would reduce the stringency of regulations affecting business services from the OECD average (i.e. France) to the low level in Sweden is associated with an increase in the size of innovative firms by around $20 \%$ in terms of employment and $30 \%$ in terms of the capital stock.

\section{Figure 13. Framework policies and resource flows to patenting firms, 2002-2010}

A: Additional labour attracted by a firm that increases its patent stock by $10 \%$

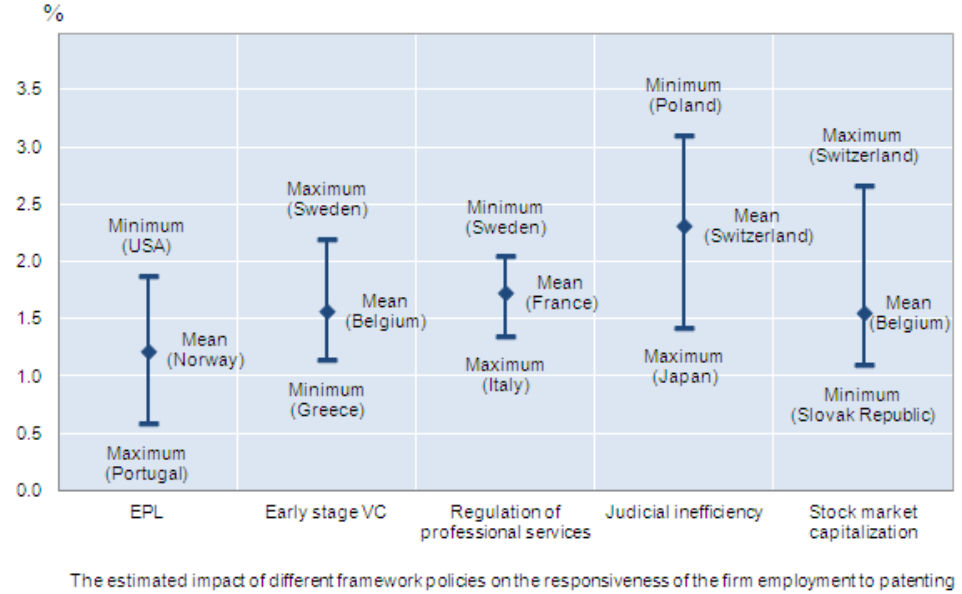

B: Additional capital attracted by a firm that increases its patent stock by $10 \%$

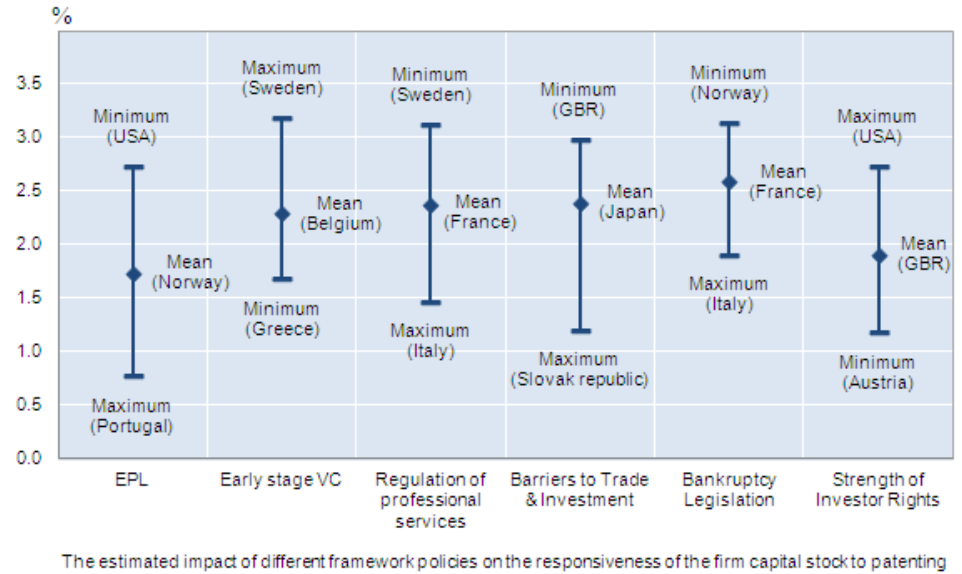

StatLink ज्ञाIs http://dx.doi.org/10.1787/888932824935

Note: The chart shows that the sensitivity of firm employment and capital to changes in the patent stock varies according to the policy and institutional environment. These estimates are obtained by including an interaction term between the Patent Stock (PatS) and policy variables in the baseline equation outlined in the notes to Figure 10. All policy terms are statistically significant at at least the $10 \%$ level. Panel A shows that the sensitivity of firm employment to patenting is three times larger when EPL is at the sample minimum (i.e. the United States), compared with when EPL is at the sample maximum (i.e, Portugal).

Source: OECD calculations based on matched ORBIS-PATSTAT data. See Andrews et al., (2013) for details. EPL is the OECD Employment Protection Legislation (EPL) sub-index of restrictions on individual dismissal of workers with regular contracts; Regulation of professional services and Barriers to Trade and Investment are sourced from the OECD Product Market Regulation (PMR) Index; Stock market capitalisation is expressed as a percent of GDP and is sourced from the World Bank along with Judicial Efficiency and Strength of Investor Rights. Judicial Efficiency refers to the cost of enforcing contracts, which measures the court costs and attorney fees as a per cent of the debt value. Strength of Investor Rights takes into account the extent of corporate disclosure, director liability and ease with which shareholder can sue company officers. See Figure 11 for details on Early Stage VC and Bankruptcy Legislation. 
Product market regulations influence the ability of economies to capitalise on innovation via rapid changes in market shares of successful firms (i.e. Stage 3 of Figure 1). Across OECD countries, less stringent regulations affecting product markets tend to be associated with higher allocative efficiency in manufacturing sectors (Figure 14A) and this relationship is confirmed by econometric analysis (Andrews and Cingano, 2012). This research also uncovers a sizeable negative effect of inappropriate service regulations on aggregate productivity, via a trickling-down effect of inefficiencies in resource allocation in the service sector. For example, a highly regulated country such as Spain would eventually experience a $4 \%$ increase in aggregate productivity if it were to reduce anti-competition barriers in the services sector to the lower level that prevails in Denmark. Importantly, reforms to regulation in the services sector tend to have stronger effects on resource allocation when labour and credit markets are more responsive, suggesting that the benefits of higher entry and competition are more fully realised when other barriers for labour and capital to flow to their most productive use are also low (Andrews and Cingano, 2012).

Figure 14. Allocative efficiency and framework policies

Selected OECD countries in 2005

\section{A. Product market regulations restricting competition}

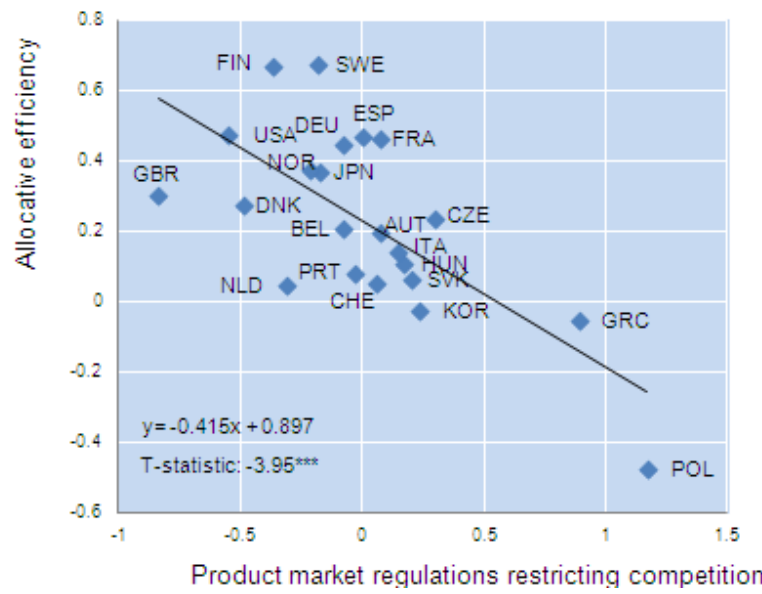

B. Creditor friendliness of bankruptcy law

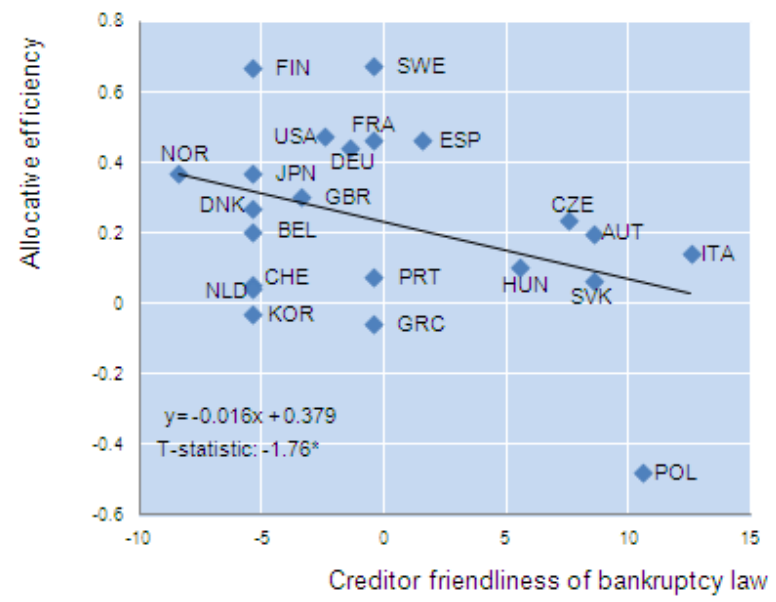

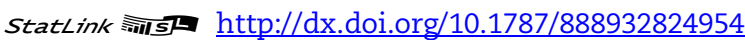

Notes: Allocative efficiency measures the contribution of the allocation of employment across firms to manufacturing labour productivity in 2005 (see Figure 7). Product market regulation refers to the overall index from of the OECD PMR for 2003. For details on Bankruptcy Legislation, see Figure 11.

Source: Andrews and Cingano (2012).

\subsubsection{Trade and investment restrictions}

The liberalisation of barriers to international trade and investment stimulates aggregate productivity (Bouis et al., 2011), by raising the scope for knowledge diffusion and technological transfer across borders (Coe and Helpman, 1995); encouraging more efficient resource allocation (Caves, 1985); and expanding market size, which raises the returns to innovation (see Section 2.1).

With respect to the formation of new ideas (i.e. Stage 1 of Figure 1), recent evidence from a sample of European firms shows that the removal of product-specific quotas (on Chinese imports into Europe) following China's accession to the WTO triggered a significant increase in R\&D, patenting and productivity (Bloom et al., 2011). Domestic innovation is also driven by knowledge spillovers from 
abroad, which will depend on the extent of openness to trade and absorptive capacity. For example, an increase in exposure to trading partner's R\&D stocks - which measures how intensively a country trades with countries that do R\&D - from the average level in Spain (around the OECD average in 2005 ) to the higher level in Canada (corresponding to the $75^{\text {th }}$ percentile across countries) is estimated to boost patents per capita by around $20 \%$ in the long run (Westmore, 2013).

With respect to the adoption of frontier technologies, trade liberalisations are likely to increase the scope for technological transfer. As such knowledge spillovers are partly embodied in imported intermediate goods, reductions in tariffs on intermediate inputs are associated with a (statistically and economically) significant increase in productivity growth in downstream manufacturing sectors (Bas et al., 2013). Moreover, to the extent that the benefits of foreign knowledge diffuse through the direct transmission of ideas rather than through trade in goods and services that embody them, barriers to foreign direct investment will hinder knowledge adoption and growth.

With respect to the latter stages of the innovation process in Figure 1, reductions in barriers to trade and investment increase the ability of patenting firms to attract the capital required to implement and commercialise new ideas (Figure 13; Panel B). Moreover, reforms to trade and investment policy improve the ability of national economies to leverage the benefits of innovation at the firm level through increases in market share of successful firms. Across service sectors in OECD countries, higher restrictions on foreign direct investment are found to be associated with lower allocative efficiency (Andrews and Cingano, 2012). These findings would imply that lowering FDI restrictions from the relatively high levels of Poland to the lower levels of Germany could be associated with a rise in the level of aggregate productivity of around $2 \%$.

\subsubsection{Job protection legislation}

By raising labour adjustment costs, stringent employment protection legislation (EPL) slows down the reallocation process (Haltiwanger et al., 2006) and aggregate productivity growth (see Bassanini et al., 2009; Autor et al., 2007). At the same time, EPL has important effects on the nature of innovation. For example, by raising exit costs, stringent EPL makes experimentation with uncertain growth opportunities - which is essential to promoting investment in KBC - less attractive. From this perspective, strict EPL curbs incentives to develop new ideas through its negative effects at the late stage of the innovation process (Figure 1).

New OECD empirical evidence shows that higher EPL lowers productivity growth by handicapping firms that operate in environment subjects to greater technological change and thus place a high option value on flexibility given their tendency to experiment with uncertain technologies. As illustrated in Figure 13, stringent EPL significantly reduces the ability of innovative firms to attract the complementary tangible resources that are required to implement and commercialise new ideas (i.e. Stage 2 of Figure 1). Moreover, the burden of this effect falls disproportionately on young firms, which is consistent with the idea that stringent EPL reduces the scope for experimentation with radical innovation.

These findings are in line with firm-level evidence that in ICT-intensive sectors where experimentation is common, more stringent EPL is associated with lower MFP growth and particularly so for firms close to the technology frontier (Andrews, 2013). Reflecting this, countries with stringent EPL tend to have smaller high-risk innovative sectors associated with intensive ICT use (Bartelsman et al., 2010), while multi-national companies tend to concentrate more technologically advanced innovation in countries with low EPL where disruptive resource shifts are easier to accommodate (Griffith and Macartney, 2010). At the same time, more stringent EPL disproportionately reduces R\&D expenditure - one indicator of the investment in the formation of new ideas (i.e. Stage 1) - in sectors with higher rates of patenting intensity, particularly in more turbulent sectors where reallocation needs are likely to be more intense. 
EPL also affects the ability of national economies to gain from successful innovations through increases in market share of innovating firms (i.e. Stage 3 of Figure 1). For example, in sectors with naturally higher reallocation needs - measured by job layoff, firm turnover and ICT intensity; e.g. electrical and optical equipment - less stringent EPL disproportionately raises allocative efficiency (Andrews and Cingano, 2012) relative to other sectors. Similarly, in more R\&D-intensive industries, less stringent EPL raises productivity growth to the extent that it is associated with a more dynamic firm growth distribution - that is, a lower share of static firms and higher share of growing and shrinking firms (Bravo-Biosca et al., 2012).

Stringent EPL also stunts the development of venture capital (VC) financing in highly volatile sectors in Europe (Bozkaya and Kerr, 2013). This occurs because strict EPL hinders the overall development of high-growth sectors in which VCs specialise and weakens the core VC business model, which relies on the aggressive reallocation of resources across the investment portfolio from failing to high-performing ventures. Importantly, however, no such trade-off emerges between VC and social protection in countries more reliant on labour market expenditures (e.g. unemployment insurance benefits) than EPL to insure workers against labour market risk. This arises because the costs of the higher general taxation required to finance labour market expenditures are not concentrated on a single margin of adjustment (like EPL), but are shared throughout the economy. Thus, well-designed social safety nets and the portability of health and pension benefits can help workers who are displaced by reallocation without imposing significant costs to resource flexibility and innovation.

While stringent EPL is undesirable from the perspective of promoting experimentation and thus investment in $\mathrm{KBC}$, it is important to recognise that employment protection might raise worker commitment and firm's incentives to invest in firm-specific human capital, which could raise withinfirm productivity (Autor, 2003; Wasmer, 2006). ${ }^{15}$ While empirical evidence for this hypothesis is scarce (see below), it nonetheless suggests that labour market reforms should be designed and implemented in a broad-based fashion. Indeed, the asymmetric liberalization of employment protection for temporary contracts while leaving in place stringent regulations on permanent contracts - which took place in many European countries - may have adverse effects on the accumulation of firm specific human capital, to the extent that firms substitute temporary for regular workers and temporary workers are less likely to participate in job-related training (see Martin and Scarpetta, 2012).

Empirical evidence for the hypothesis that stringent EPL might be beneficial to innovation and within-firm productivity via these channels is scarce. Acharya et al., (2010) find a positive relationship between EPL and patenting based on a sample of five countries and argue that strict EPL ex ante fosters innovation by making it less likely that firms would dismiss workers in the event of short-run project failures. ${ }^{16}$ New OECD research, however, cannot confirm this relationship in a broader sample of countries (Westmore, 2013). Nevertheless, there is some evidence to support the idea that stringent EPL is less detrimental in industries characterised by cumulative innovation processes, where innovation-driven labour adjustments are more likely to be accommodated through the skillupgrading of existing employees than worker turnover. For example, Andrews and Cingano (2012) find that while strict EPL has an adverse effect on resource allocation in highly turbulent innovative sectors, this is not the case in sectors characterised by cumulative patterns of innovation (such as the chemicals sectors).

${ }^{15}$ Of course, this argument should not be overstated since even in environments where EPL is low, firms may choose to carry out internal training programmes if it is in their business interests and other bonding devices exist.

16 In this model, it is assumed that stronger EPL provides a commitment device for a firm not to fire its employee in instances where the project failure occurs due to sheer bad luck. This leads employees to exert more effort and disproportionately increase their investment in innovative projects relative to routine projects. 


\subsubsection{Bankruptcy legislation}

Similar to stringent EPL, bankruptcy laws that impose excessively high exit costs in the event of business failure may make entrepreneurs less willing to experiment with risky technologies. At the same time, bankruptcy codes that provide no safeguards for creditors may reduce the supply of credit, so some balance is required.

Bankruptcy regimes that severely penalise failed entrepreneurs, whether by forcing liquidation more often or limiting entrepreneurs' ability to start new businesses in the future, are likely to reduce the willingness to take risks and thus the supply of new ideas (Peng et al., 2010; de Serres et al., 2006). Similarly, studies that control for the possibility that economic outcomes influence bankruptcy regimes (i.e. reverse causality) find that more debtor-friendly bankruptcy codes have been associated with greater intensity of patent creation, patent citations and faster growth in countries relatively more specialised in innovative industries (Acharya and Subramanian, 2009). At the same time, more debtor-friendly bankruptcy codes are associated with more rapid technological diffusion, which enables laggard countries to catch-up with the technological frontier (Westmore, 2013).

The right balance between leniency and protection of creditors in bankruptcy legislation will also depend on specific features of entrepreneurs' activities. Bankruptcy legislation that does not excessively penalise failure - as measured by a lower cost to close a business - can promote the flow of capital to more innovative firms (Figure 13, Panel B; Andrews et al., 2013), by reducing the expectation of entrepreneurs that they will be heavily penalised in case of failure. By contrast, if the cost of winding-down a business is particularly high, risky entrepreneurial ventures might not be brought to the market to avoid incurring high exit costs in case of failure. Indeed, bankruptcy codes that more heavily penalise failure are negatively associated with MFP growth and the share of high growth firms in capital intensive industries (Bravo-Biosca et al., 2012). Finally, across OECD countries, less stringent bankruptcy legislation is to some extent associated with higher allocative efficiency (Figure 14, Panel B), and this effect is particularly strong in sectors with naturally higher firm turnover rates where regulations affecting exit costs are most likely to bind (Andrews and Cingano, 2012).

The swift reallocation of resources from failed ventures will also be affected by the time required for the full completion of all legal procedures to wind up a business and the obstacles to the use of out of courts arrangements. In extreme cases, these legal procedures might take years to complete, thus undermining effective reallocation and the accumulation of entrepreneurial capital.

Finally, well-designed legal systems can support efficient resource allocation (Haltiwanger, 2011), raise the returns to innovation (Nunn, 2007). For example, in countries with more efficient judicial systems - proxied by a lower cost of enforcing contracts - labour flows more readily to patenting firms (Figure 13, Panel A).

\subsection{Innovation-specific are policies are important but trade-offs emerge}

Private investment may be at or above socially desirable level for some types of KBC (e.g. branding), but government intervention is warranted to compensate for market failures in the provision of innovative effort, such as $R \& D$. This section discusses a range of innovation policies with special focus on their effects on the formation of new ideas (i.e. Stage 1 of Figure 1), and the possible unintended consequences on reallocation mechanisms which are central to the latter stages of the framework in Figure 1. However, some key risks with such innovation policies is that they might: i) support activities that would have taken place even in the absence of the support; ii) distort or reduce innovation effort; and iii) like many policy instruments, be prone to rent seeking,. The design of such schemes should thus aim to minimise wasteful expenditures (OECD, 2006), and since robust evidence on the effectiveness and optimal design of innovation policies is still scarce, more effective costbenefit analyses of policies are also required. 


\subsubsection{Fiscal incentives for $R \& D$}

R\&D tax incentives, a non-discriminatory tool that aims to reduce firms' marginal cost of R\&D activities, are present in 27 of the 34 OECD member countries, and also in Brazil, China, India and the Russian Federation. Support for business R\&D through the tax system is typically combined with a broader set of direct support policies (e.g. grants, loan, loan guarantees) that are also intended to address market failures related to investment in innovation. While significant cross-country differences exist in the policy mix (Figure 15), there has recently been a general shift away from direct support (Figure 16) and R\&D tax incentives have become more generous (OECD, 2009).

\section{Figure 15. Direct government funding of business R\&D (BERD) and tax incentives for R\&D}

Budget impact as a percentage of GDP; 2010 or latest year available

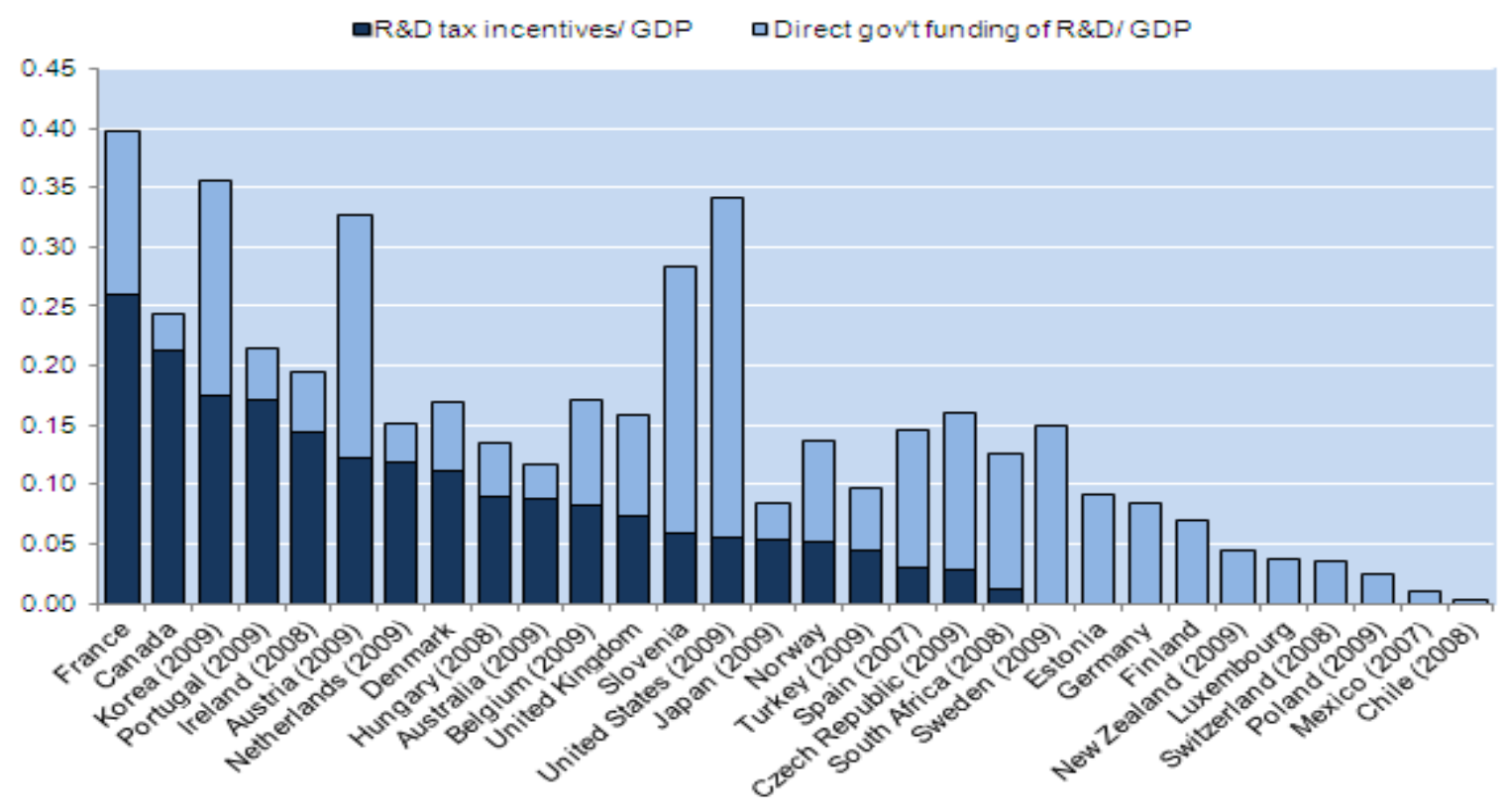

StatLink ज्ञाIs http://dx.doi.org/10.1787/888932824973

Notes: Countries ranked from highest to lowest R\&D tax incentives/GDP. R\&D tax incentives do not cover sub-national incentives. Direct government funding includes grants and public procurement of R\&D and excludes repayable loans. Figures are not shown for Greece, Israel, Italy, the Slovak Republic, China and the Russian Federation, which provide R\&D tax incentives, but cost estimates are not available. For the United States, direct government funding of R\&D includes defence spending on R\&D by the government in the form of procurement contracts or the subcontracting by government agencies of non-classified projects to private firms. That is, it includes only R\&D spending not directly performed by national or publicly funded institutions (e.g. military laboratories etc). If a project is conducted by the private firm in direct collaboration with the government, publicly funded institutions or universities, only the part that is done by the private firm and paid to her would be included.

Source: OECD, Main Science and Technology Indicators (MSTI) Database, June 2012; OECD R\&D tax incentive questionnaires of January 2010 and July 2011; OECD (2011a) and national sources.

These trends should be assessed in light of the new evidence suggesting that: i) while R\&D tax incentives remain a useful policy instrument, direct support measures might be more effective in raising R\&D than previously thought; ii) the precise features of both kinds of policies determine both their cost to tax payers and their unintended consequences. It would seem, therefore, that issues related to the design of such schemes should take precedence over mere increases in their generosity. 
Moreover, it is important to recognise that cross country differences exist in the policy design and administration of both R\&D tax incentives and direct support measures. R\&D tax incentives differ significantly across countries in the extent to which they target different firms or specific areas (Table 2), while the composition of direct programmes (i.e. loans, loan guarantees, grants, etc) can vary across countries. These differences should be kept in mind when interpreting the following discussion.

Figure 16. R\&D tax incentives versus direct support to business R\&D, 2004 and 2009

Cost forgone of tax revenues on R\&D for USD 1 of direct support

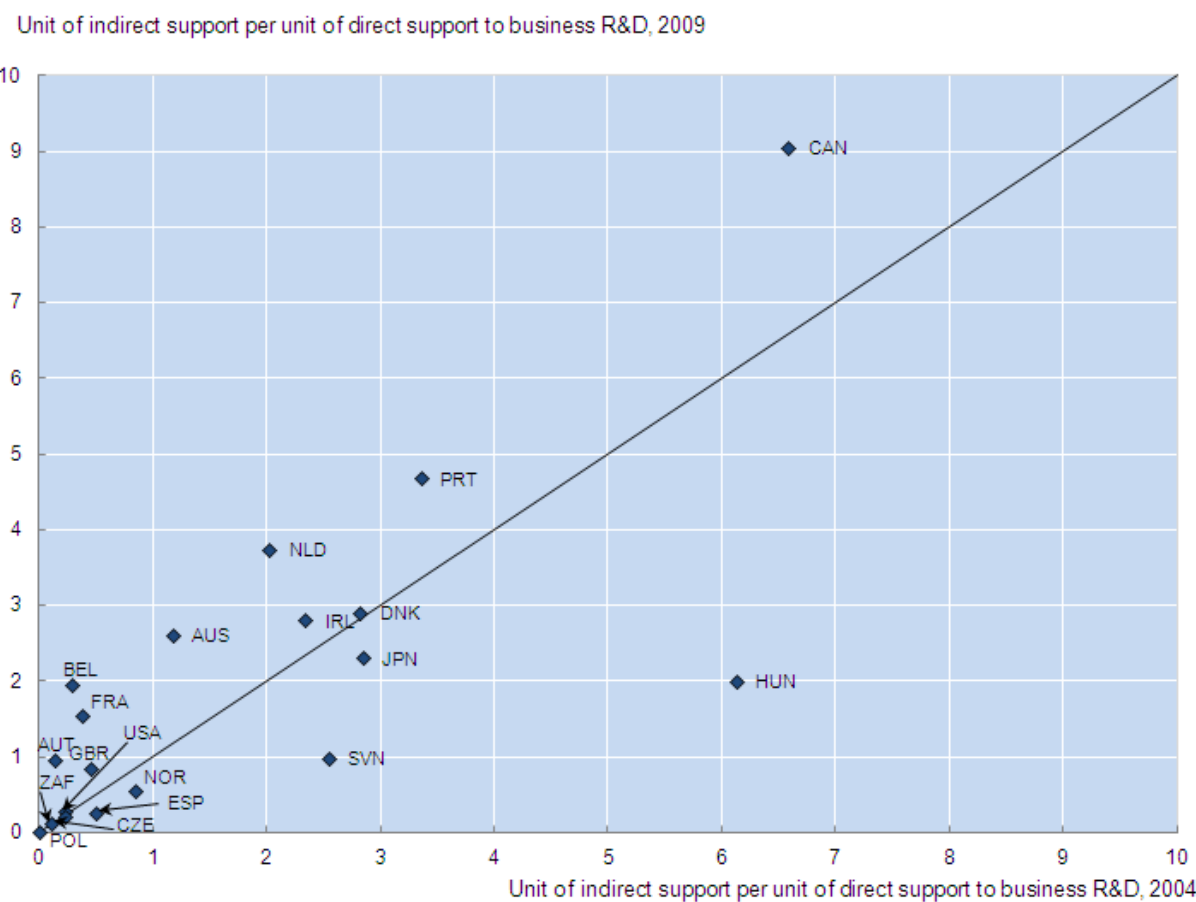

StatLink जins http://dx.doi.org/10.1787/888932824992

Source: OECD (2011a)

\section{Effectiveness of R\&D tax incentives and direct support measures}

Estimates of the private "R\&D price elasticity" imply that a $10 \%$ reduction in the user cost of $R \& D$ increases the volume of private sector R\&D spending by about $1 \%$ in the short run and $10 \%$ in the long run (Bloom et al., 2002). ${ }^{17}$ The greater responsiveness in the long run reflects adjustment costs (Hall and van Reenen, 2000) and is consistent with the effectiveness of an R\&D tax incentive being limited if the supply of scientists and engineers is not sufficiently elastic (Goolsbee, 1999). New OECD evidence is broadly consistent with these conclusions. For example, a $6 \%$ increase in the generosity of $R \& D$ tax incentives - e.g. from the level in the United States to the level in Japan in 2008 - is estimated to increase the level of R\&D by about $6 \%$ in the long run (Westmore, 2013).

17 User costs are captured by the B-index (Warda, 2001), which measures the present value of before-tax income that a firm needs to generate in order to cover the cost of an initial R\&D investment and to pay the applicable income taxes. See Westmore (2013) for more details. 
The effectiveness of R\&D tax incentives, however, also depends on the stability of the policy regime over time (Guellec and van Pottelsberghe, 2003). In countries that have experienced a high number of $R \& D$ tax policy reversals, the estimated impact of $R \& D$ tax incentives on private $R \& D$ expenditure appears to be greatly diminished (Westmore, 2013).

Table 2. Details of differences in R\&D tax incentive schemes across selected countries (2013)

\begin{tabular}{|c|c|c|}
\hline \multirow{4}{*}{$\begin{array}{l}\text { Design of the } \\
\text { R\&D tax } \\
\text { incentive } \\
\text { scheme }\end{array}$} & Volume base $R \& D$ tax credit & $\begin{array}{l}\text { Australia*, Austria, Belgium (capital), Canada, Chile, } \\
\text { Denmark, France, Norway. }\end{array}$ \\
\hline & Incremental R\&D tax credit & United States (mostly)**. \\
\hline & $\begin{array}{l}\text { Hybrid system of a volume and an } \\
\text { incremental credit }\end{array}$ & Ireland, Italy, Japan, Korea, Portugal, Spain. \\
\hline & $R \& D$ tax allowance & $\begin{array}{l}\text { Belgium (capital), Brazil, China, Chile, Columbia, } \\
\text { Czech Republic, Finland, Hungary, India, Netherlands, } \\
\text { Russian Federation, Singapore, Slovenia, South Africa, } \\
\text { Turkey, United Kingdom. }\end{array}$ \\
\hline \multicolumn{2}{|c|}{ Payroll withholding tax credit for $R \& D$ wages } & Belgium, Hungary, Netherlands, Spain, Turkey. \\
\hline \multicolumn{2}{|c|}{$R \& D$ tax incentive is not refundable } & $\begin{array}{l}\text { Brazil, China, Chile, Columbia, Czech Republic, India, } \\
\text { Italy, Japan, Korea, Poland, Portugal, Russia, Singapore, } \\
\text { Slovenia, South Africa, United States (mostly)**. }\end{array}$ \\
\hline \multicolumn{2}{|c|}{$\begin{array}{c}\text { R\&D tax incentive does not contains carry-over } \\
\text { provisions }\end{array}$} & Austria, Brazil, Columbia, Italy, Norway. \\
\hline \multicolumn{2}{|c|}{ More generous R\&D tax incentives for SMEs } & $\begin{array}{l}\text { Australia, Canada, France, Hungary, Japan, Korea, } \\
\text { Netherlands, Norway, Portugal, United Kingdom. }\end{array}$ \\
\hline \multirow{4}{*}{ Targeting } & Special for energy & United States (volume-based). \\
\hline & Special for collaboration & Hungary, Italy, Japan, Norway. \\
\hline & Special for new claimants & France. \\
\hline & Special for young firms and start-ups & Belgium, France, Netherlands, Portugal. \\
\hline \multicolumn{2}{|c|}{ Ceilings on amounts that can be claimed } & $\begin{array}{l}\text { Austria, Denmark, France, Ireland, Italy, Japan, } \\
\text { Netherlands, Norway, Portugal, Singapore, Spain, } \\
\text { United Kingdom, United States. }\end{array}$ \\
\hline \multicolumn{2}{|c|}{ R\&D Income-based R\&D tax incentives } & $\begin{array}{l}\text { Austria (individuals), Belgium, China, France, Hungary, } \\
\text { Luxembourg, Netherlands, Spain, Turkey, United } \\
\text { Kingdom. }\end{array}$ \\
\hline \multicolumn{2}{|c|}{$\begin{array}{l}\text { Special treatment of technology acquisitions } \\
\text { (capital cost) }\end{array}$} & Poland \\
\hline \multicolumn{2}{|r|}{ No $R \& D$ tax incentives } & $\begin{array}{l}\text { Estonia, Germany, Israel, Mexico (repealed), New } \\
\text { Zealand (repealed), Sweden, Switzerland. }\end{array}$ \\
\hline
\end{tabular}

Note: R\&D tax allowances are tax concessions up to a certain percentage of the R\&D expenditure and can be used to offset taxable income; R\&D tax credits reduce the actual amount of tax that must be paid. No R\&D tax incentives means no R\&D tax credit or allowance but does not preclude accelerated depreciation allowances. *On 17 February 2013 , the Australian Government announced that companies with aggregated turnover of AUD20 billion (about USD21 billion) or more will no longer be eligible for the R\&D tax incentive. This change will apply to income years commencing on or after 1 July 2013 , but is yet to be legislated. ${ }^{*}$ Qualified energy consortia in the United States are eligible for a volume-based R\&D tax credit and refundable tax credits.

Source: OECD Directorate of Science, Technology and Industry. Based on information available as at March 2013. 
New OECD research also shows that direct government subsidies can encourage additional business R\&D (Westmore, 2013). However, this result does not hold when the analysis is conducted on data pre-dating the 2000s, which is consistent with earlier research that did not find any significant relationship between direct $R \& D$ subsidies and additional private $R \& D$ spending over the period 19822001 (Jaumotte and Pain, 2005). The estimated increase in effectiveness of R\&D direct support may reflect a shift in the structure of public support, which has become more focused on subsidies for commercial R\&D activities and with matching grants being a more common feature of government funding programmes (see Blanco Armas et al., 2006; Hall and Maffioli, 2008). ${ }^{18}$

Evidence on the relative effectiveness of these policy instruments in stimulating intramural R\&D is scarce. A study for Norway (Hægeland and Moen, 2007) suggests that an additional \$1 of tax credits had a somewhat larger effect on R\&D than an additional \$1 of direct support. While estimating these "bang for the buck" multipliers in a cross-country setting is more complicated and requires a number of restrictive assumptions, the available evidence suggests a larger impact of direct support than volume-based tax incentives on R\&D (Westmore, 2013). ${ }^{19}$ As discussed below, however, the impact of $R \& D$ tax incentives and direct support mechanisms may vary across different types of firms.

While fiscal incentives (i.e. R\&D tax incentives and direct support) boost R\&D expenditure, it is important that they ultimately raise productivity growth to the extent that such programmes carry associated compliance and administration costs. R\&D tax incentives and direct support could be expected a priori to have positive effects on productivity growth, since both policies lead to additional business R\&D and business R\&D has important effects on productivity growth (Westmore, 2013). However, direct empirical evidence on the impact of $R \& D$ tax incentives and direct support on productivity growth is less clear-cut (Brouwer et al., 2005; Lokshin and Mohnen, 2007; Westmore, 2013).

The failure to find a clear-cut direct positive effect of fiscal incentives for R\&D on productivity growth could reflect measurement and identification issues, but could also arise if:

- R\&D fiscal incentives lead to an increase in the price of R\&D (e.g. via higher wages of scientists) as opposed to the volume of $R \& D$. Recent estimates suggest that this wage effect could reduce the effectiveness of R\&D tax incentives (in terms of the volume of R\&D) by 10\% (Lokshin and Mohnen, 2008) to 30\% (Haegeland and Møen (2007). This suggests that the effectiveness of such schemes could be enhanced by education policies that raise the supply of skilled workers.

- Projects financed by R\&D tax incentives have lower than average marginal productivity (Hægeland and Moen, 2007) and might not be the projects with the highest social rate of return (i.e. highest knowledge spillovers). For example, evidence suggests a positive effect of R\&D tax incentives on incremental innovations that are new to the firm (e.g. Czarnitzki et al., 2005; de Jong and Verhoeven, 2007) but not on innovations new to the market (Cappelen et al., 2012).

- $R \& D$ tax incentives may lead to $R \& D$ duplication or a re-labelling of existing non-R\&D activities as R\&D investment (Lemaire, 1996; Hall and Van Reenen, 2000). However, tentative evidence suggests such policies are unlikely to lead to significant increase in re-labelling of investment (Westmore, 2013).

18 Bloch and Graversen (2008) note that past government support for R\&D was often by contracts whereby governments would fund as well as procure the output of firms' R\&D activity. This may have meant that much of the R\&D performed was not directly commercially viable, limiting the size of knowledge spillovers from the $R \& D$ across firms and industries.

19 These estimates assume a volume-based R\&D tax incentive regime for computational ease. However, caution is warranted in interpreting these results since single country econometric exercises suggest that the bang-forthe-buck multiplier is much larger for incremental based schemes than volume based schemes (Lokshin and Mohnen, 2008). 
- Information problems limit governments' ability to channel direct support measures to those projects that have the highest potential.

- The firms that benefit most from R\&D fiscal incentives are actually those for which R\&D is less likely to generate large spillovers and significant increases in aggregate productivity growth. While smaller - but not necessarily younger - firms tend to be more responsive to R\&D tax incentives than larger firms (Lokshin and Mohnen, 2007; Hægeland and Moen, 2007). The aggregate impact of R\&D tax incentives might be dwarfed if such firms are more likely to focus on niche markets (Bloom et al., 2013b).

\section{The importance of policy design}

It is likely that the above issues could be exacerbated by specific design features of innovation policies. Moreover, design is crucial to minimise the cost to tax payers and the unintended consequences of such innovation policies. ${ }^{20}$

New OECD evidence suggests that R\&D tax incentives have the unintended consequence of protecting incumbents to the detriment of potential entrants, thus slowing down the reallocation process (Bravo-Biosca et al., 2012). Figure 17 shows that more generous R\&D tax credits are associated with a less dynamic distribution of firm growth in R\&D intensive sectors - i.e. a higher share of stagnant firms and a lower share of shrinking firms - thus disproportionally benefiting the slowest growing incumbent firms. Accordingly, R\&D tax incentives might embody an important trade-off from the perspective of the KBC-innovation-reallocation nexus. At the same time, differences in the extent of direct support - as measured by the share of business R\&D financed by government - do not appear to shape the distribution of firm employment growth, suggesting that such policies have a more neutral impact on incumbents vis-a-vis entrants. ${ }^{21}$

To the extent that R\&D tax incentive schemes in some countries lack immediate cash refunds and/or carry-over provisions (Table 3), the design of such schemes may provide less assistance to young firms, which are typically in a loss position in the early years of an R\&D project. Indeed, the lack of an immediate refund may significantly reduce the effective rate of the tax subsidy to R\&D, even in countries that provide relatively generous support at first glance (Elschner et al., 2011). The use of payroll withholding tax credits for R\&D wages, whereby firms receive an immediate refund for expenditure on the wages for R\&D personnel, is another way to provide support for (young) firms that are in a loss position.

Even if R\&D tax incentive schemes are refundable and contain carry-over provisions, young firms may not fully benefit from such schemes if they lack the upfront funds required to start an innovative project. Direct public funding might be more beneficial than R\&D tax incentives for young financially constrained firms (Busom et al., 2012) if direct support helps to certify the "good quality" of young firms and projects. This could reduce problems associated with information asymmetry (e.g. Lerner, 1999; Blanes and Busom, 2004), which tend to be much more pronounced for radical - as opposed to incremental - innovations (Czarnitzki and Hottenroot, 2011). This in turn would lower the cost of capital of firms receiving grants when applying for external sources of financing.

20 R\&D fiscal incentives could also be designed to incorporate a countercyclical dimension (Aghion et al., 2009; López-García et al., 2012). See Andrews and de Serres (2012) for a discussion.

${ }^{21}$ Indeed, this is consistent with recent evidence from Finland and Germany which shows that direct support schemes do not preserve the dominance of market leaders but make small firms more likely to undertake R\&D (Czarnitzki and Ebersberger, 2010). 


\section{Figure 17. More generous R\&D fiscal incentives are associated with a more static distribution of firm growth in R\&D-intensive industries}

The differential impact of $R \& D$ tax incentives on the share of firms in each employment growth grouping

口Norway

Share (percentage points)

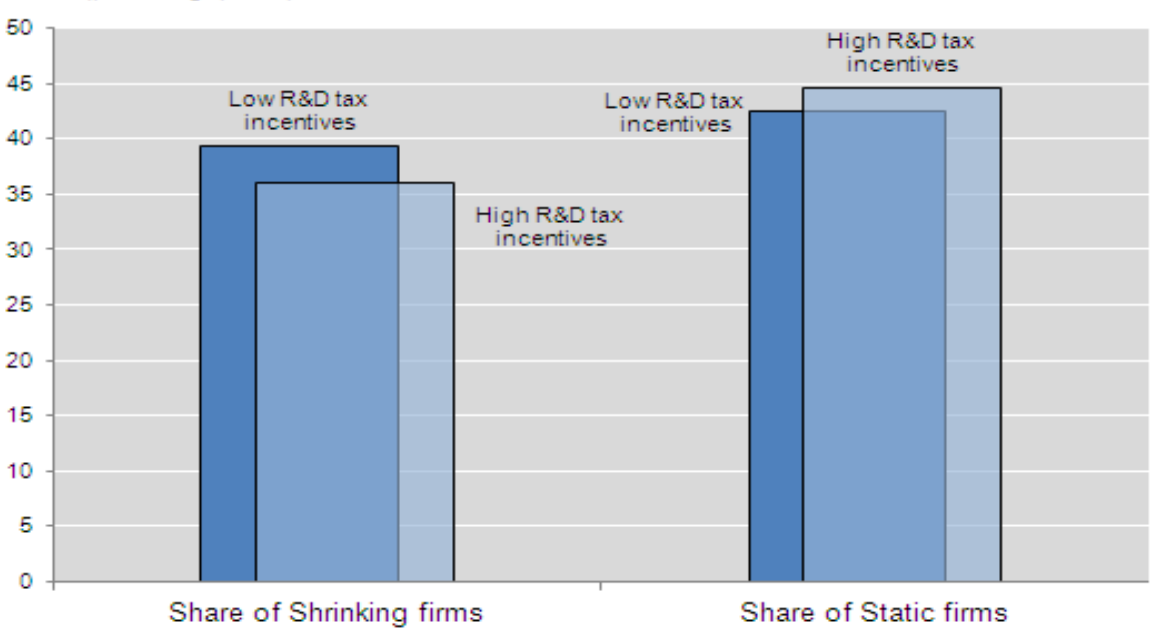

StatLink ज्ञाI St http://dx.doi.org/10.1787/888932825011

Notes: The figure shows a numeric example of how more generous R\&D tax incentives affect the distribution of firm employment growth, based on the (statistically significant) coefficient estimates in Bravo-Biosca et al., (2012). The darker columns show the estimated shares of shrinking and static firms in an R\&D intensive industry (Electrical and optical equipment; NACE rev. 1.1. 30-33) in a country with relatively low R\&D tax incentives (e.g. Norway). In turn, the lighter shaded columns show the estimated shares of shrinking and static firms in the electrical and optical equipment sector if Norway were to adopt more generous R\&D tax incentives (e.g corresponding to the level of R\&D tax subsidies in Spain).

Source: Bravo-Biosca et al., (2012).

It is important, however, that any allocation of direct support should be non-automatic and be based on competitive, objective and transparent selection - e.g. by involving in the selection process independent international experts. While such a process obviously involves administrative and compliance costs, subsidies allocated on a selective basis tend to have larger direct effects on firm productivity than automatic subsidies and enable recipient firms to signal their quality to potential investors (Colombo et al., 2011). More broadly, a well-designed and transparent system of direct support measures might be complementary to the use of R\&D fiscal incentives as it might help direct public funding to high-quality projects with high social returns (e.g. relevant to green growth and population aging) and through targeting, may limit forgone tax revenues.

Design issues are also important to minimise the fiscal cost of public support for innovation:

- Incremental tax incentives (i.e. which only apply to R\&D expenditures above some baseline amount) are found to be more effective in inducing additional business R\&D spending than volume based tax credits (Parsons and Phillips, 2007; Lokshin and Mohnen, 2009). Thus, they are less costly from a fiscal perspective since they are less likely to subsidise R\&D activity that would have occurred in absence of the policy. While incremental tax incentives are likely to be preferable to volume-based schemes, the uptake of such schemes by young and small firms might be limited somewhat by compliance costs associated with such schemes (e.g. accountants might be required to calculate the base etc). 
- Governments should factor in that the actual cost of the policy will depend also on the success/uptake of the policy, which at the time of design might be difficult to predict, especially if the policy triggers a response from multi-national enterprises (MNEs). Indeed, more generous R\&D tax incentives abroad are associated with lower levels of domestic R\&D, all else equal, reflecting the tendency for $R \& D$ tax incentives to tilt MNE's location decisions for R\&D activities amongst very similar locations (Criscuolo et al., 2009). At the same time, new OECD research shows that the fact that MNEs can use cross-border tax strategies to shift profits generated by KBC across countries (OECD, 2013a; Karkinsky and Riedel, 2012) might lead to unintentionally high levels of total tax support for $R \& D .^{22}$ In addition, $R \& D$ tax incentives may unintentionally create scope for rent-seeking behaviour that might adversely affect resource allocation and lead to tax competition. Indeed, the increasing generosity of $R \& D$ tax incentives in comparable countries may pressure countries that do not offer them to introduce similar measures.

While the evidence presented above suggests that a policy framework that utilises a mix of incremental R\&D tax incentives and selective direct grants might be optimal, it is important to keep in mind that the administrative and compliance costs associated with such schemes might be higher than for volume and automatic subsidies. However, it is unlikely that such administrative and compliance costs will be as high as the forgone tax revenue associated with policy measures that support activity that would have taken place in absence of the scheme.

Finally, it is crucial that the evaluation of these policies is factored into the policy at the design stage to ensure longer run cost-effectiveness. This can be done at a relatively low cost and could entail, for example, ex ante collection of data and ex post full access to data and disclosure of relevant information for independent evaluation agencies as well as experimental policy design ex ante (e.g. randomisation of participants; use of pilot phases etc.).

\subsubsection{Non-business sector $R \& D$ and collaborative research}

Some R\&D activities have high social value, but the commercial applications of their output and the appropriability of the potential benefits may be highly uncertain. This is often the case for basic research that is fundamental to future innovations and has the greatest economic benefit when accompanied by full public disclosure. In such circumstances, governments may perform (as well as fund) some research themselves through universities or public laboratories.

While public research has been at the root of some revolutionary technologies (Sheehan and Wyckoff, 2003), the lags can be long and variable and thus difficult to identify empirically. ${ }^{23}$ In fact, evidence ranges from a positive effect of basic research on private R\&D investment (Falk, 2004; Jaumotte and Pain, 2005) to significant crowding out (Guellec and Van Pottelsberghe, 2003). Allowing for firm heterogeneity, new OECD research finds that increases in government basic research spending (as a per cent of GDP) are associated with higher firm-level MFP growth in R\&D intensive sectors (Andrews, 2013), in line with survey-based evidence (Cohen et al., 2002).

The initial stage of idea formation (e.g. Stage 1 in Figure 1) may also involve collaboration between private firms and public research entities, especially for young firms that are less likely to have access to their own research facilities. Indeed, collaboration between firms and research entities in conducting R\&D has become increasingly common in OECD countries (OECD, 2002), reflecting the growing complexity of innovation, the need for complementary knowledge and the heightened attractiveness of such partnerships in a fiscally-constrained environment. New OECD evidence shows

22 Tax policy may also be encouraging the migration of $\mathrm{KBC}$ to offshore holding companies, and the use of $\mathrm{KBC}$ in foreign rather than domestic production. Consequently, tax revenues from R\&D and domestic knowledge spillovers may be lower than in the absence of R\&D tax incentives.

${ }^{23}$ Furthermore, some public R\&D may not be directly focused on fostering commercial innovation, but on other areas such as environmental protection, public health and national security. 
that more collaboration - as proxied by the share of higher education R\&D financed by industry - is also associated with stronger productivity growth for firms in R\&D intensive sectors (Andrews, 2013).

Some countries seek to foster these linkages through fiscal incentives for firms that collaborate with a public research institution. Public support is often justified on the basis that: i) cooperative projects are more akin to basic research than other projects; and ii) universities produce knowledge that is more valuable to firms than firms are actually aware of. However, it is unclear whether fiscal incentives for collaboration can be justified on the basis of a traditional market failure argument and evidence on the effectiveness of such policies is scarce (Criscuolo et al., 2009). ${ }^{24}$

\subsubsection{The role of intellectual property rights}

The legal means to protect rights on intellectual property (IP) embedded in different types of $\mathrm{KBC}$ include patents, copyrights, trademarks and design rights. In each case, the primary aim is to preserve incentives to innovate by granting holders the (temporary) ability to exclude others from using an invention. By pushing firms to innovate, competition also plays an important role in fostering innovation. The central policy challenge is to strike an effective balance between exclusive rights and competition rules so that the application of one does not undermine the effectiveness of the other. While this has been a long-standing issue, a key question is whether the growing importance of information technology and other KBC-intensive industries has altered the nature of the trade-off. A number of factors suggest that this may be the case, at least for patents. ${ }^{25}$

\section{Balancing the incentives to innovation with the broad diffusion of knowledge}

Patents grant temporary monopolies to inventors in exchange for public disclosure of the technical information relating to the innovation. Such public disclosure is important in fostering further technological advancement, as follow-on innovators may learn from and build upon the patented invention. The patent system can also play a role in easing financial constraints for young firms, as patents may serve as collateral or signals/certifications to investors (Haussler et al., 2012; Danguy et al., 2009). Since markets for KBC are underdeveloped, patents also serve as a mechanism to facilitate technology trade through their sale or licensing.

Patents also entail costs. Exclusivity can provide market power to the rights holder, the impact of which varies according to the importance of the protected innovation as an input into other activities, as well as to the availability of alternatives. Patents can also raise transactions costs for follow-on innovators, via search costs to ensure that they are not infringing patent rights and legal costs in case of litigation procedures.

While the strengthening of patent protection in recent years has been accompanied by a substantial increase in the number of patents, it is unclear whether this reflects higher innovation or a more widespread use of patents (Lerner, 2002). Evidence from the United States suggests important differences across sectors, with patents more likely to be associated with an increase in innovation in the pharmaceutical, biotechnology and specific chemical sectors (Arora et al., 2001; Graham et al., 2009). This is consistent with the fact that the boundaries of the innovation may be clearer in these sectors, but also that the invention process is neither particularly cumulative nor highly fragmented (Hall and Harhoff, 2012). This contrasts with information technology (IT) industries, where it is common to see products made of multiple components, each covered by numerous patents (FTC, 2011).

${ }^{24}$ Recently, Belgium, Denmark, Hungary, Italy, Spain, Canada and Japan have offered such inducements.

25 The focus is on patents for sake of brevity but other forms of intellectual property are obviously important. See Andrews and de Serres (2012) and Hargreaves (2011) for a discussion. 


\section{Complementarities with competition policy}

Given the strengthening of patent protection, it is essential that the competitive forces motivating innovation and the diffusion of ideas are not stifled. The complementarity of patent protection and product market regulation settings is highlighted by OECD evidence that finds a positive relationship between the strength of patent regimes and the number of patent applications per capita, but only in countries with pro-competition product market regulations (Westmore, 2013; OECD 2006). Similarly, increases in patenting rates have a stronger association with MFP growth when product market regulations are lower, reflecting the easier implementation and commercialisation of new ideas in more competitive markets (Section 4.1.1) and the ability for a larger number of firms to capitalise on the related knowledge spillovers when barriers to entry are low (Westmore, 2013).

While patents are a key mechanism to provide firms with an incentive to innovate, they may have unintended consequences in some sectors. In rapidly growing domains such as information and communication technology (ICT), the patent system may unduly favour incumbents at the expense of young firms, thus undermining incentives to invest in KBC. Empirical evidence from the United States suggests that the cost of litigation exceeded the profit from patents in the late 1990s in industries outside pharmaceuticals and chemicals (Bessen and Meurer, 2008). Indeed, the increasing emergence of "patent aggregators" (PAs) that accumulate software patents with the sole objective of extracting rents from innovators may challenge innovation activities. While PAs could improve the reallocation of $\mathrm{KBC},{ }^{26}$ analysis of the results from litigations prompted by PAs finds evidence of substantial deadweight losses (Bessen, et al., 2012). While pro-competitive product market regulations are crucial, patent systems can also contain safeguards - such as compulsory licensing - to address the market power concerns. In this regard, a key issue is whether compulsory licensing blunts the incentives to innovate but evidence on the impact of such provisions is scarce (see Andrews and Criscuolo, 2013).

\section{The patent system and the KBC economy}

Finally, the emergence of "patent thickets" - i.e. webs of overlapping IPRs (Shapiro, 2001) ${ }^{27}$ - can result in firms paying licensing fees to multiple parties or having production held-up as they try to commercialise new technology (UK IPO, 2011). Such patent thickets may affect market entry and disproportionally disadvantage young firms with little bargaining power (Cockburn et al., 2009) and reduce the probability that young firms obtain financing (Cockburn and MacGarvie, 2007).

\subsection{Financing and corporate reporting in the knowledge-based economy}

For knowledge-based firms, profitability partly depends on the ability to leverage investments in $\mathrm{KBC}$ through rapid increases in the scale of production, which requires access to complementary tangible resources that typically need to be funded through external finance. New OECD evidence shows that via their effect on reallocation mechanisms, deeper financial markets play an important role in helping firms to implement and commercialise new ideas, thus raising the returns to innovation. For example, resource flows to innovative firms tend to be stronger in countries with higher stock market capitalisation to GDP (Figure 13, Panel A; Andrews et al., 2013). Similarly, deeper financial markets are associated with a more dynamic distribution of firm growth (i.e. more growing

26 They do so notably by acquiring patents from bankrupt companies, by organising patent auctions and by helping businesses to obtain the rights to use ideas through licensing arrangements (see Chien, 2009).

27 These are webs of overlapping IPRs for which the rights are held by competing firms (Shapiro, 2001). They may be most common in fields in which innovation is relatively cumulative or there is incentive for firms to hold patents for defensive or strategic purposes. 
and shrinking firms and fewer static firms) in industries that are highly dependent on external finance (Bravo Biosca et al., 2012). ${ }^{28}$

While the size and development of financial markets matters for innovative firms (Aghion et al., 2005), insufficient collateral may limit access to external financing for heavily KBC reliant firms. Traditional debt and equity markets are primarily designed to fund tangible assets that have well defined market prices and can serve as collateral. In contrast, KBC assets are less easy to define and collateralisation is often affected by such assets being non-separable and non-transferable - two impediments to the mobility of any single asset across parties and the realisation of full salvage value in the event of firm bankruptcy. Difficulties in collateralising KBC also arise from the uncertainty and perceptions of risk that characterises $\mathrm{KBC}$, which tend to amplify information asymmetries in lending markets. The importance of collateral is well documented in modern macroeconomic theory, with a long line of literature - beginning with Kiyotaki and Moore (1997) - using the magnifying effects of collateral availability to explain business cycle fluctuations.

\subsubsection{Corporate reporting of $K B C$}

For many firms, such capital market imperfections are typically addressed through greater corporate disclosure, such as through the release of financial accounting statements (Healy and Palepu, 2001). Indeed, high quality corporate disclosure regimes can promote a more efficient resource allocation (EC, 2003) and firm growth in sectors that are more dependent on external finance (Rajan and Zingales, 1998). The benefits arising from corporate disclosure, however, are more difficult to realise for firms heavily reliant on KBC. Given the property of only partial excludability, firms cannot reduce asymmetric information via full disclosure due to the risk that imitators will appropriate any rents arising from their $\mathrm{KBC}$. More fundamental, perhaps, is the inability of current corporate accounting frameworks to properly deal with KBC. To be recorded in company accounts, intangibles must adhere to five strict criteria but there is a clear disconnect between these accounting attributes and the economic characteristics of KBC (Hunter et al., 2005). For example, the nonseparability characteristic - partly due to the tendency for KBC to be embodied in people - is clearly at odds with the identifiability criterion (see attribute (a) in Box 2). ${ }^{29}$

\section{Box 2. Treatment of intangible assets in International Accounting Standards (IAS)}

As outlined in Hunter et al., (2005), intangibles are only recorded in the accounting system as assets if the items, first, meet the asset definition criteria and, second, meet the asset recognition criteria. $^{1}$

Asset definition criteria for intangibles comprise three attributes:

a) Identifiability: $i$ ) the asset is separable, being capable of being separated or divided from the entity and sold, transferred, licensed, rented or exchanged, either individually or together with a related contract, asset or liability; or ii) the asset arises from contractual or other legal rights, regardless of whether those rights are transferable or separable from the entity or from other rights and obligations ${ }^{2}$;

b) Control: "an entity controls an asset if the entity has the power to obtain the future economic benefits flowing from the underlying resource and to restrict the access of others to those benefits."

c) Future economic benefits: benefits flowing from an intangible asset that may include

${ }^{28}$ Financial market development in this study is measured as the sum of the stock and bond market and of private credit by banks, all normalised over GDP.

${ }_{29}$ There is also a tension between the limited appropriability and inherent uncertainty of intangibles on the one hand, and the capacity to control the asset and the probability of future benefits required for accounting purposes (attributes (b) and (d) in Box 2). 
revenue from the sale of products or services, cost savings, or other benefits resulting from the use of the asset by the entity. ${ }^{4}$

Asset recognition criteria for intangibles comprise two attributes:

d) It must be probable (presumably more than $50 \%$ probable) that the economic benefits embodied in the asset will eventuate; and

e) The asset must possess a cost that can be measured reliably. ${ }^{5}$

1. IAS 38 Intangible Assets, paragraph18.

2. IAS 38 Intangible Assets, paragraph 12.

3. IAS 38 Intangible Assets, paragraph 13.

4. IAS 38 Intangible Assets, paragraph 17.

5. IAS 38 Intangible Assets, paragraph 17.

From an economic standpoint, the adherence to such strict accounting criteria leads to an inadequate - but also arbitrary and ad hoc - treatment of KBC in corporate accounting (Hunter et al., 2005). While internally-generated intangibles are expensed, otherwise indistinguishable intangibles that are acquired externally (as a complete set) through the market are treated as assets since they are separable and have a verifiable cost. These deficiencies in formally accounting for KBC are particularly worrying in the light of empirical evidence which shows that in sectors that are more dependent on external finance, growth in R\&D expenditure as a share of value-added is higher in countries with higher quality corporate disclosure regimes (Carlin and Mayer, 2000).

Relatively few analysts currently advocate for better recognition of KBC in financial statements, but there is a case for non-financial metrics to encourage firms to disclose information on their investments in intangibles (e.g. so-called narrative reporting; see OECD, 2008). Even with respect to narrative reporting, progress has been hampered by the fact that very few jurisdictions have introduced guidelines to facilitate such reporting. In principle, policymakers could leverage existing reporting frameworks to encourage firms to report on their intangible assets through developing voluntary national guidelines, though a more concerted global dialogue on $\mathrm{KBC}$ disclosure is also necessary.

\subsubsection{Financing $K B C$ and macro-financial stability $K B C$}

Given the inherent difficulties in collateralising $\mathrm{KBC}$ assets, financial markets have been hesitant to provide debt financing to KBC-intensive firms (Jarboe, 2008) and thus KBC has traditionally been financed out of retained earnings (Hall and Lerner, 2009). Nevertheless, KBC-backed lending rose significantly in the United States in the lead-up to the financial crisis (Loumioti, 2011). For example, between 1997 and 2005, the share of secured syndicated loans collateralised by KBC in total secured loans rose from $11 \%$ to $24 \%$ and this trend was largely underpinned by the activities of unregulated lenders - i.e. investment banks - that did not face the same regulatory constraints as commercial banks in valuing KBC as collateral. While it is possible that the use of KBC as loan collateral was a symptom of the general deterioration in lending standards during this period, the limited available evidence is consistent with the idea that the the collateralisation of KBC was an innovation, whereby lenders allocated capital prudently based on an assessment of the economic characteristics of the prospective borrowers (see Loumioti, 2011; Andrews and Criscuolo, 2013).

Reforms such as Basel III - to the extent that they make banking safer and more stable - are clearly desirable. However, given the risk that more stringent capital requirements could reduce the supply - or increase the cost - of capital for risky business enterprises in the short-term (Aghion et al., 2013), it will be interesting to see how this affects the financing prospects of firms reliant on KBC. 


\subsubsection{Some consequences of the financial crisis for $K B C$}

Systematic evidence on how firms reliant on KBC have fared in capital markets since the financial crisis is limited. Indeed, although recessions typically provide firms with an opportunity to restructure at low cost (Hall, 1991), it is important to recognise the damage that the financial crisis may have caused to the financing prospects of KBC-intensive firms. Existing evidence highlights the disproportionate adverse effects of financial crises on net firm entry (Caballero and Hammour, 2005), which is likely to reduce the scope for experimentation with new ideas and thus investment in KBC (Ziebarth, 2012; Buera and Moll, 2012). An important risk at the current juncture is that near-zero interest rate policy and distortions in the financial sector sustain highly inefficient firms, thereby preventing the release of resources to underpin the expansion of innovative firms. Indeed, aggregate productivity performance in Japan during the 1990s was held back by the tendency for resources to increasingly be trapped in "Zombie firms", as credit continued to be extended to such firms, despite their poor economic fundamentals (Caballero et al., 2008).

\subsubsection{Policies to nurture seed and early stage financing}

Financing constraints tend to be more acute for young firms to the extent they have limited internal funds and lack a track record to signal their "ability" to investors. Indeed, when asymmetric information problems are large, a "missing markets" problem may emerge where many of the innovations associated with young start-up firms may never be commercialised. This financing gap is partly bridged by venture capitalists or business angels, who address informational asymmetries by intensively scrutinising firms before providing capital and monitoring them afterwards (Hall and Lerner, 2009; OECD 2011b). Countries with more developed seed and early stage venture capital markets tend to invest more heavily in $\mathrm{KBC}$ and also appear to be more effective at channelling capital and labour to young innovative firms (Figure 13). ${ }^{30}$ More broadly, econometric studies based on the variation in venture capital (VC) financing that is exogenous to the arrival of entrepreneurial opportunities, tend to find that VC has a sizeable positive impact on innovation and economic growth (Kortum and Lerner, 2000; Samila and Sorenson, 2011).

Nevertheless, the question of why seed and early stage VC (SES-VC) financing is higher in some countries than others remains (Figure 18). It is likely that differences in human capital, entrepreneurial attitudes and framework and innovation policies will play a role. For example, less stringent EPL (Section 4.1.3) and bankruptcy regimes, characterised by strong exit mechanisms and that do not excessively penalise business failure, can foster the development of SES-VC (Armour and Cumming, 2006), while high rates of taxation on corporate incomes and capital gains have negative effects on SES-VC (Da Rin et al., 2006). Regulatory barriers might also impact the availability of SESVC, particularly with respect to the ease with which venture capitalists and business angels can organise themselves as limited liability entities (OECD, 2013b). ${ }^{31}$ Finally, with respect to the clean technology sector, new OECD evidence suggests that regulations that aim to create a market for these technologies are associated with a higher level of VC investment while fiscal incentives for investment in these technologies are not effective (Criscuolo and Menon, 2013). ${ }^{32}$

30 The impact of early stage seed capital on resource flows to patenting firms is only statistically significant for young firms (see Andrews et al., 2013).

${ }^{31}$ For example, BA groups in Mexico cannot organise themselves as limited liability entities (OECD, 2013b). This has important consequences both for the legal standing of minority shareholders and for issues related to trust management and execution of guarantees that have to be ensured by courts in Mexico.

32 This likely reflects the frequent changes in the availability and generosity of such measures, further underscoring the importance of a predictable policy environment for the financing of innovative ventures. 
Figure 18. Venture capital investment as a percentage of GDP, 2009

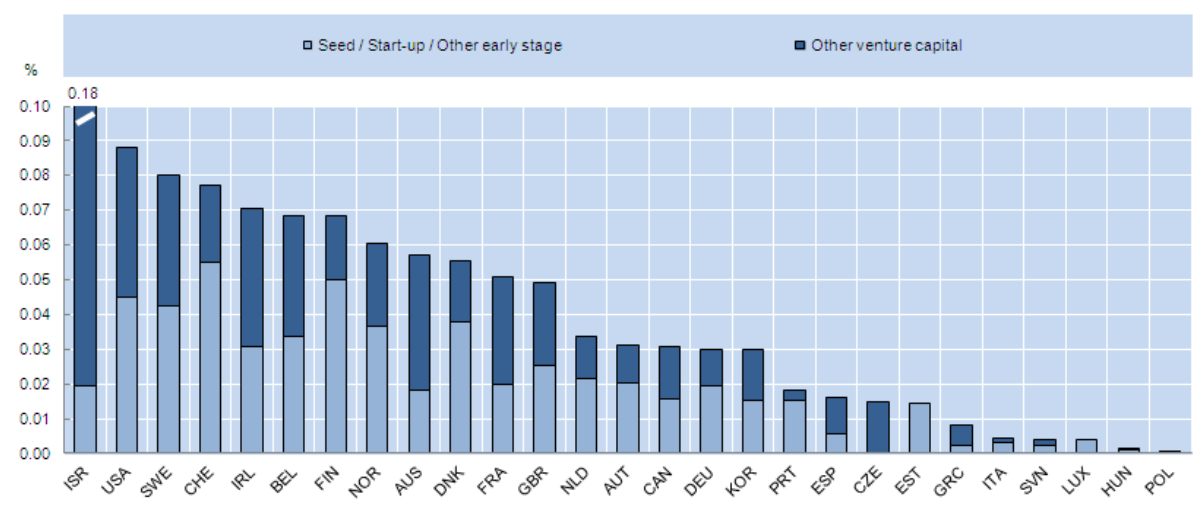

Source: OECD (2011b).

StatLink *ins http://dx.doi.org/10.1787/888932825030

Governments attempt to nurture the market for seed capital through a range of supply-side policy initiatives (Wilson and Silva 2013). Most OECD countries have some type of government equity finance programme, such as direct public VC funds, "funds of funds" - an investment strategy consisting of holding a portfolio of other investment funds rather than investing directly in companies - and co-investment funds, whereby public funds are matched to those of private investors who are approved under the scheme. These programmes, especially funds of funds and coinvestment funds, have grown in importance over the past five years. While fiscal incentives are less common, some 17 OECD countries still employ either "front-end" tax incentives or tax deductions for investment in seed and early stage VC and "back-end" tax relief on capital gains, including rollover or carry forward of capital gains or losses. Of course, it is important to keep in mind the broader taxation environment - and particularly the existence of capital gains tax - when assessing these specific fiscal incentives.

Evidence on the contribution of supply side policy interventions in the market for SES-VC is scarce and research on whether public VC funds crowd-out private activity is inconclusive (Da Rin et al., 2012). Given the potential for regulatory capture (Lerner, 2008), however, government funding is likely to be most effective when it remains disciplined by private venture capital and does not exert actual control over business decisions (Brander et al., 2011). This suggests that public co-investment funds and fund-of-funds might be preferable to public equity funds but evidence on this issue is limited and the effect is likely to be contingent on the design of such schemes. More broadly, preliminary, albeit crude, evidence (Da Rin et al., 2013) shows that the more support for SES-VC there is in a country - as proxied by the number of tax and equity policy instruments - the lower is the age at which firms receive SES financing. Although causation is difficult to establish and the ultimate performance of firms that receive public funding is unclear, this might suggest that such programmes warrant further attention and that further analysis to examine the effectiveness of these schemes is called for.

Some countries institute portfolio restrictions that bar or limit institutional investors (e.g. pension funds, insurance companies) from carrying out investments in SES-VC, though comparable cross-country information in this area is incomplete. These restrictions may be important, in light of existing research which shows that VC activity in the United States increased significantly, following the removal of restrictions on pension funds in 1979 (Kortum and Lerner, 2000). Similarly, the existence of viable exit markets for venture investments, particularly the existence of secondary stock markets (e.g. the NASDAQ), increases the expected return to investors and entrepreneurs and 
stimulates the development of markets for seed capital (Da Rin et al., 2006). ${ }^{33}$ This suggests that rules affecting initial public offerings will also be important.

\section{Policy reform options to raise $\mathrm{KBC}$ and innovation}

This section provides a short overview of the policy conclusions of the paper, and discusses some policy issues that may emerge from these findings.

\subsection{Appropriate framework policies raise the returns to investing in $K B C$}

Regulations that promote flexibility in product, labour and credit markets and bankruptcy laws that do not excessively penalise failure can encourage firms to experiment with uncertain growth opportunities and raise the expected net benefits of KBC investment by making it easier for successful firms to implement and commercialise new ideas. While policy reforms that promote competition in domestic and global product markets have pervasive impacts on the KBC-innovation-reallocation nexus, the impact of bankruptcy legislation and EPL is more nuanced and trade-offs with other policy goals may emerge.

Less stringent EPL and bankruptcy laws that do not excessively penalise business failure are desirable to the extent that they reduce exit costs and thus encourage firms to experiment with new forms of KBC. Policy reforms along these lines, however, may shift the distribution of risk from entrepreneurs to workers and creditors. Thus, for example, reforms to job protection legislation could be accompanied by broader mechanisms that insure workers against labour market risk, such as welldesigned social safety nets and portable health and pension benefits. More generally, while efficient reallocation mechanisms raise the returns to $\mathrm{KBC}$, the shifting of resources also entails costs for workers and firms, which raises questions regarding the role - and most effective design - of structural adjustment packages. Bankruptcy regimes that punish failure less severely are desirable to the extent that they encourage experimentation with risky technologies, but such arrangements could in principle discourage investment in $\mathrm{KBC}$ due to a possible reduction in credit supply. Striking the right balance between these two forces makes the design of bankruptcy provisions complicated. More generally, the issue of bankruptcy legislation and exit costs raises important questions about the optimal level of risk-taking in an economy, which however are beyond the scope of this paper.

\subsection{Rethinking innovation policies by focusing on policy design}

The analysis of innovation policies, oriented toward direct support measures and increasingly R\&D tax incentives in many countries, highlights that their design is crucial, not only to deliver maximum effectiveness, but also to minimise the fiscal cost and possible unintended consequences of such policies. One concrete policy recommendation to emerge is that R\&D tax incentives should be refundable (or allow for payroll withholding tax credits for R\&D wages) and contain carry-over provisions in order to make them more compatible with the needs of young firms. From a fiscal perspective, incremental R\&D tax incentives might be more cost-effective than volume-based schemes in raising $R \& D$. It is also likely that well-designed, selective and transparent direct support measures are complementary to the use of R\&D tax incentives as it might help channel public funding to high-quality projects with high social returns, but in each case, the administrative cost of such schemes should be taken into account. Consideration should also be given to the public funding of basic research and to institutional frameworks that foster collaboration in innovative activities but more policy evaluations in these areas are needed. Indeed, this reaffirms the idea that innovation policies should be designed to allow for the ex post evaluation of their effectiveness.

33 Secondary stock markets specialised in high-tech firms have traditionally constituted a popular exit route, owing to their lower costs and less stringent admission requirements relative to first-tier markets. 
It is vital that IPR protection is coupled with pro-competition product market policies to ensure that the market power of incumbents does not stifle the creativity of new entrants. In some emerging $\mathrm{KBC}$ sectors where the innovation process is typically fragmented (e.g. software), ${ }^{34}$ the marginal costs of patent protection may already outweigh its benefits. Indeed, while the rise of patent aggregators could, in principle, improve the reallocation of $\mathrm{KBC}$ assets, they may have the unintended consequence of stifling radical innovations owing to the transaction and entry costs they place on young firms. Given the importance of the patent system to other sectors such as pharmaceuticals and chemicals, this raises an important policy dilemma for governments, which is yet to be resolved in academic and policy circles.

\subsection{Trade-offs between $K B C$ and other policy priorities}

This paper has identified a policy reform agenda to boost $\mathrm{KBC}$, but it is not clear that gearing public policy to maximise the growth potential of $\mathrm{KBC}$ will always have unambiguously positive effects, and trade-offs may emerge with other policy goals. For example, a possible tension lies between promoting an increasingly knowledge-based economy and keeping a lid on rising inequality. This may place heightened focus on education and adult learning policies that enable workforce skills to adjust in a fashion that is more complementary to the changes in labour demand that are often associated with technological progress. To the extent that those needs are fulfilled, rising investment in $\mathrm{KBC}$ might translate into higher aggregate productivity growth without greatly exacerbating income inequality (Goldin and Katz, 2008).

\section{Bibliography}

Acemoglu, D. and J. Linn (2004), "Market Size in Innovation: Theory and Evidence from the Pharmaceutical Industry”, Quarterly Journal of Economics, 119(3), pp. 1049-1090.

Acharya, V.V. and K.V. Subramanian (2009), "Bankruptcy Codes and Innovation", Review of Financial Studies 22 (12): 4949-4988.

Acharya, V.V., R.P. Baghai and K.V. Subramanian (2010), "Labour Laws and Innovation", NBER Working Paperseries, No. 16484.

Aghion, P. et al. (2004), "Entry and Productivity Growth: Evidence From Microlevel Panel Data." Journal of the European Economic Association, April-May, 2(2-3). pp. 265-276.

Aghion, P. et al. (2005), "Competition and Innovation: An Inverted-U Relationship", Quarterly Journal of Economics, 120(2), pp. 701-728.

Aghion, P, P. Howitt and D. Mayer-Foulkes. (2005), "The Effect Of Financial Development On Convergence: Theory And Evidence," Quarterly Journal of Economics, 120(1), pp. 173-222.

Aghion, P., and P. Howitt (2005), “Appropriate Growth Policy: A Unifying Framework”, Journal of European Economic Association, April-May.

Aghion, P., D. Hemous, and E. Kharroubi (2009), “Credit Constraints, Cyclical Fiscal Policy and Industry Growth”, NBER Working Paper No. 15119.

Aghion, P. et al., (2013), "Investing for Prosperity: Skills, Infrastructure and Innovation", Rapport de la LSE Growth Commission.

Altomonte, C. (2010), "Reform and Growth: Microfounding 'Europe 2020", Presentation. Available online at: http://www.irer.it/convegni/archivioeventi/eventi-2010/seminario-produttivitaimprese/reformand-growth-micro-founding-europe-2020

\footnotetext{
${ }^{34}$ In the software industry, products are often made of multiple components, each covered by numerous patents.
} 
Andrews, D. and F. Cingano (2012), "Public Policy and Resource Allocation: Evidence from Firms in OECD countries", OECD Economics Department Working Papers, No.996, OECD, Paris.

Andrews, D. and A. de Serres (2012), "Intangible Assets, Resource Allocation and Growth: A Framework for Analysis", OECD Economics Department Working Papers, No.989, OECD, Paris.

Andrews, D., C. Criscuolo and C. Menon (2013), "Do Resources Flow to Innovative Firms? CrossCountry Evidence from Firm-Level Data" OECD Economics Department Working Papers, forthcoming, OECD, Paris.

Andrews, D. and C. Criscuolo (2013), "Knowledge Based Capital, Innovation and Resource Allocation", OECD Economics Department Working Papers, No.1047, OECD, Paris.

Andrews, D. (2013), "Policy Determinants of TFP Growth: Evidence from firms in OECD countries", Mimeo (See Appendix 1 of Andrews and Criscuolo, 2013).

Armour, J. and D. Cumming (2006), “The Legislative Road to Silicon Valley”, Oxford Economic Papers.

Arora, A., A. Fosfuri and A. Gambardella. (2001), "Markets for Technology and Their Implications for Corporate Strategy," Industrial and Corporate Change 10(2), pp. 419-51.

Australian Productivity Commission (2007), "Public Support for Science and Innovation", Australian Productivity Commission.

Autor, D., L. Katz, and A. Krueger (1998), "Computing Inequality: Have Computers Changed the Labor Market?”, Quarterly Journal of Economics, CXIII, pp. 1169-1214.

Autor, D.H. (2003), "Outsourcing at Will: the Contribution of Unjust Dismissal Doctrine to the Growth of Employment Outsourcing", Journal of Labor Economics, 21(1)), pp. 1-42.

Autor, D.H., W.R. Kerr and A.D. Kugler (2007), "Do Employment Protections Reduce Productivity? Evidence from US States", Economic Journal, 117, F189-F217.

Bartelsman, E.J., S. Scarpetta and F. Schivardi (2003), "Comparative Analysis of Firm Demographics and Survival: Micro-Level Evidence for the OECD Countries", OECD Economics Department Working Papers, No. 348, OECD, Paris.

Bartelsman, E.J., (2004), "Firm Dynamics and Innovation in the Netherlands: A Comment on Baumol", De Economist 152(3), 353-363.

Bartelsman, E.J. and H.L.F. De Groot (2004), "Integrating Evidence on the Determinants of Productivity”, in G. Gelauff, L. Klomp, S. Raes, Th. Roelandt (Eds.), Fostering Productivity: Patterns, Determinants and Policy Implications, Amsterdam e.a.: Elsevier, pp. 160-184.

Bartelsman, E.J., J. Haltiwanger and S. Scarpetta (2004), "Microeconomic Evidence of Creative Destruction in Industrial and Developing Countries", IZA Discussion Paper No 1374

Bartelsman, E.J. and J. Hinloopen (2005), “Unleashing Animal Spirits: Investment in ICT and Economic Growth", in L. Soete and B. ter Weel (eds.), The Economics of the Digital Society, Edward Elgar, pp. $272-304$.

Bartelsman, E.J., E. Perotti and S. Scarpetta (2008), "Barriers to Exit, Experimentation and Comparative Advantage", RICAFE2 Working Paper No. 056, London School of Economics.

Bartelsman, E.J., P.A. Gautier and J. De Wind (2010), “Employment Protection, Technology Choice, and Worker Allocation", IZA Discussion Paper No. 4895. 
Bartelsman, E.J., J. Hatltiwanger and S. Scarpetta (2012), "Cross-Country Differences in Productivity: The Role of Allocation and Selection", forthcoming in: American Economic Review.

Bas, M., Å. Johansson, F. Murtin and G. Nicoletti (2013), "Do Lower Tariffs on Foreign Intermediate Inputs Raise Productivity? Panel Data Evidence for OECD Countries" OECD Economics Department Working Papers, forthcoming, OECD, Paris.

Bassanini, A., L. Nunziata and D. Venn (2009), "Job Protection Legislation and Productivity Growth in OECD Countries", Economic Policy, Vol. 24, pp. 349-402.

Benner, M.J. and M. Tushman (2002), "Process Management and Technological Innovation: A Longitudinal Study of the Photography and Paint Industries", Administrative Science Quarterly, 47(4), pp. 676-706.

Bessen, J. and M.J. Meurer (2008), Patent Failure: How Judges, Bureaucrats and Lawyers Put Innovators at Risk, Princeton University Press.

Bessen, J,, J. Ford and M.J. Meurer (2012), “The Private and Social Costs of Patent Trolls, Do Nonpracticing Entities Benefit Society by Facilitating Markets for Technology?”, Regulation.

Bhide, A. (2000), The Origin and evolution of New Businesses, Oxford University Press, New York, NY.

Blanco Armas, E., et al. (2006), "Public Financial Support for Commercial Innovation: Europe and Central Asia Knowledge Economy Study Part 1", World Bank Chief Economist's Regional Working Paper Series, Vol. 1, no. 1.

Blanes, J.V. and I. Busom (2004), "Who Participates in R\&D Subsidy Programs? The Case of Spanish Manufacturing Firms", Research Policy 33(10): 1459-1476.

Bloch, C., and E.K. Graversen (2008), “Additionality of Public R\&D Funding in Business R\&D”, The Danish Centre for Studies in Research and Research Policy, Working Paper 2008/5.

Bloom, N. and J. Van Reenen (2002), "Patents, Real Options and Firm Performance”, Economic Journal 111, C97-C116.

Bloom, N., R. Griffith and J. Van Reenen (2002), "Do R\&D Tax Credits Work?", Journal of Public Economics 85:1-31

Bloom, N. and J. Van Reenen (2010), "Why Do Management Practices Differ across Firms and Countries?”, Journal of Economic Perspectives 24(1), pp. 203-224.

Bloom, N., M. Draca and J. Van Reenen (2011), “Trade Induced Technical Change: The Impact of Chinese Imports on Innovation, Diffusion and Productivity", Mimeo. http://www.stanford.edu/ nbloom/TITC.pdf

Bloom, N., C. Genakos, R. Sadun and J. Van Reenen (2012a), "Management Practices Across Firms and Countries", NBER Working Paper, No 17850.

Bloom, N., R. Sadun and J. Van Reenen (2012b), “Americans Do IT Better: US Multinationals and the Productivity Miracle”, American Economic Review 102(1): 167-201.

Bloom, N., B. Eifert, A. Mahajan, D. McKenzie and J. Roberts (2013a), "Does Management Matter: Evidence from India", Quarterly Journal of Economics Vol. 128(1), pp. 1-51.

Bloom, N., M. Schankerman and J. Van Reenen (2013b), "Identifying Technology Spillovers and Product Market Rivalry", Econometrica. forthcoming. 
Bouis, R., R. Duval and F. Murtin (2011), "The Policy and Institutional Drivers of Economic Growth Across OECD and Non-OECD Economies: New Evidence from Growth Regressions", OECD Economics Department Working Papers, No. 843, OECD, Paris.

Bourlès, R., et al. (2010), "Do Product Market Regulations in Upstream Sectors Curb Productivity Growth?: Panel Data Evidence for OECD Countries", OECD Economics Department Working Papers, No. 791, OECD, Paris.

Bozkaya, A. and W.R. Kerr (2013), "Labor Regulations and European Venture Capital”, Journal of Economics \& Management Strategy (forthcoming).

Brander, J., Q. Du and T. Hellmann (2011), “The Effects of Government-Sponsored Venture Capital: International Evidence“,“, NBER Working Paper No. 16521.

Bravo-Biosca, A. (2010), Growth Dynamics: Exploring Business Growth and Contraction in Europe and the US", NESTA and FORA, London.

Bravo Biosca, A., C. Criscuolo and C. Menon (2012),"What Drives the Dynamics of Business Growth?", STI Working Paper, forthcoming.

Bresnahan,T.F., E. Brynjolfsson and L.M. Hitt (2002), "Information Technology, Workplace Organization, and the Demand for Skilled Labor: Firm-Level Evidence", Quarterly Journal of Economics 117(1), pp. 339-376

Brouwer. E., T. Grosfeld, P. den Hertog and T. Poot (2005), "Evaluation of a Major Dutch Tax Credit Scheme (WBSO) aimed at promoting R\&D, mimeo.

Brynjolfsson, E., A. Renshaw and V. Marshall Alstyne (1997), "The Matrix of Change: A Tool for Business Process Reengineering", Sloan Management Review, pp. 37-54.

Brynjolfsson, E., A. McAfee, F. Zhu, and M. Sorell (2008), "Scale Without Mass: Business Process Replication and Industry Dynamics", SSRN eLibrary.

Brynjolfsson, E, and A. McAfee (2011), Race Against The Machine: How the Digital Revolution is Accelerating Innovation, Driving Productivity, and Irreversibly Transforming Employment and the Economy, Digital Frontier Press.

Buera, F.J. and B. Moll (2012), “Aggregate Implications of a Credit Crunch”, Mimeo.

Busom, I., B. Corchuelo and E. Martínez-Ros (2012), "Tax Incentives and Direct Support for R\&D: What Do Firms Use and Why?," Business Economics Working Papers id-11-03, Universidad Carlos III, Instituto sobre Desarrollo Empresarial "Carmen Vidal Ballester".

Caballero, R. J. and M.L. Hammour (2005), "The Cost of Recessions Revisited: A Reverse-Liquidationist View," Review of Economic Studies, 72(2), pp. 313-341.

Caballero, R.J., T. Hoshi and A.K. Kashyap (2008), "Zombie Lending and Depressed Restructuring in Japan", American Economic Review, 98(5): 1943-77.

Cappelen, Å., A. Raknerud and M. Rybalka (2012), "The Effects of R\&D Tax Credits on Patenting and Innovations", Research Policy, 41(2), pp. 334-345.

Carlin, W. and C. Mayer (2000), "Finance, Investment and Growth". Working Paper. University of Oxford.

Caves, R.E. (1985), "International Trade and Industrial Organization: Problems, Solved and Unsolved", European Economic Review 28 (August): pp. 377-395. 
Chien, C. (2009), "Of Trolls, Davids, Goliaths, and Kings: Narratives and Evidence in the Litigation of High-Tech Patents", North Carolina Law Review 87, pp. 1571-1615.

Choi, A.S., (2008), "Entrepreneurs Turn Business Failure into Success" Bloomberg Business Week, 16 October 2008.

Ciccone, A. and E. Papaioannou (2007), "Red Tape and Delayed Entry", Journal of the European Economic Association, 5(2-3), pp. 444-458.

Cockburn, I.M. and M. MacGarvie (2007), "Patents, Thickets, and the Financing of Early-Stage Firms: evidence from the software industry”, NBER Working Paper, No. 13644.

Cockburn, I.M., M.J. MacGarvie and E. Muller (2009), "Patent Thickets, Licensing and Innovative Performance”, ZEW Discussion Paper, No. 08-101.

Coe, D.T. and E. Helpman (1995), "International R\&D Spillovers", European Economic Review, Vol. 39, pp. 859-887.

Cohen, W.M., R.R. Nelson and J.P. Walsh (2002), “Links and Impacts: The Influence of Public Research on Industrial R\&D”, Management Science Vol. 48(1), pp. 1-23.

Colombo, M.G., L. Grilli and S. Murtinu (2011), "R\&D Subsidies and the Performance of High-Tech Start-Ups", Economics Letters, 112(1), pp. 97-99.

Conway, P., D de Rosa, G Nicoletti and F Steiner, (2006), "Product Market Regulation and Productivity Convergence", OECD Economic Studies, Vol. 2006(2), pp. 39-76, OECD Publishing, Paris.

Corrado C., C. Hulten and D. Sichel (2005), "Measuring Capital and Technology: An Expanded Framework", in Measuring Capital in the New Economy, C. Corrado, J. Haltiwanger, and D. Sichel, eds., Studies in Income and Wealth, Vol. 65, Chicago: The University of Chicago Press.

Corrado, C., J. Haskel., C. Jona-Lasinio and M. Iommi (2012), "Intangible Capital and Growth in Advanced Economies: Measurement Methods and Comparative Results", INTAN-Invest Mimeo.

Crespi, G., C. Criscuolo and J. Haskel, (2008), "Productivity, Exporting, and the Learning-by-Exporting Hypothesis: Direct Evidence from UK Firms," Canadian Journal of Economics, 41(2), pp. 619-638.

Criscuolo, C., D. Czarnitzki, C. Hambro and J. Warda (2009), "Design and Evaluation of Tax Incentives for Business Research and Development: Good Practice and Future Development”, final report submitted by the Expert Group on Impacts of R\&D Tax Incentives to the European Commission, Directorate General - Research, 15 November.

Criscuolo, C., J.E. Haskel and M.J. Slaughter (2010), “Global Engagement and the Innovation Activities of Firms," International Journal of Industrial Organization, 28(2): pp. 191-202.

Criscuolo, C. and C. Menon (2013), "Feeding Green Ideas: Risk Finance in the Cleantech Sector", forthcoming DSTI Working Paper, OECD, Paris.

Czarnitzki, D., P. Hanel and J.M. Rosa (2005), "Evaluating the Impact of R\&D Tax Credits on Innovation: A Microeconometric Study on Canadian Firms", Centre interuniversitaire de recherche sur la science et la technologie, Note de recherche 2005-02, Montreal, Canada.

Czarnitzki, D. and B. Ebersberger (2010), "Do Direct R\&D Subsidies Lead to the Monopolization of R\&D in the Economy", ZEW Discussion Paper No. 10-078, Mannheim.

Czarnitzki, D., and H. Hottenrott (2011), "Financial Constraints: Routine Versus Cutting Edge R\&D Investment", Journal of Economics and Management Strategy 20(1), pp. 121-157. 
Danguy, J., G. de Rassenfosse and B. Van Pottelsberghe de la Potterie (2009), “The R\&D-Patent Relationship: An Industry Perspective”, European Investment Bank Papers, Vol. 14, No.1, pp. 170-195.

Da Rin, M., G. Nicodano A. Sembenelli (2006), "Public policy and the creation of active venture capital markets", Journal of Public Economics 90, pp. 1699- 1723.

Da Rin, M., T.F. Hellmann and M. Puri (2012), “ A Survey of Venture Capital Research”, in George Constantinides, Milton Harris, and René Stulz (eds.) Handbook of the Economics of Finance, Vol 2, Amsterdam, North Holland.

Da Rin, M. et al., (2013), “The Market for Seed and Early Stage Financing and Supply-Side Policy Initiatives", Mimeo (Results are summarised in Appendix 3).

De Jong, J.P.J., and W.H.J. Verhoeven (2007), "WBSO Evaluation 2001-2005: Impacts, Target Group Reach and Implementation, EIM, Zoetermeer and UNU-MERIT, Maastricht, The Netherlands.

De Serres, A., S. Kobayakawa, T. Sløk and L. Vartia (2006), "Regulation of Financial Systems and Economic Growth", OECD Economics Department Working Papers, No. 506, OECD, Paris.

Easterly, W. and R. Levine (2001), "It's Not Factor Accumulation: Stylized Facts and Growth Models", World Bank Economic Review, 15(2), pp. 221-224.

Elschner, C., C. Ernst, G. Licht and C. Spengel (2011), "What the Design of an R\&D Tax Incentive Tells About is Effectiveness: A Simulation of R\&D Tax Incentives in the European Union", Journal of Technological Transfer 36, pp. 233-256.

Eisenberg, R. and R. Ziedonis (2010), “Markets for Patents”, Research Conference, Technology Academics Policy.

EC (2003), Study on the Measurement of Intangible Assets and Associated Reporting Practices.

Falk, M. (2004), “What Drives Business R\&D Intensity Across OECD Countries?”, WIFO Working Papers, 236, WIFO.

Fisman, R.J. and V. Sarria Allende (2010), "Regulation of Entry and the Distortion of Industrial Organization", Journal of Applied Economics, 13(1), pp. 91-111.

FTC (2011), The Evolving IP Marketplace: Aligning Patent Notice and Remedies with Competition, Federal Trade Commission.

Gambardella, A. (2008), "Ideas for Rent: An Overview of Markets for Technology", presented at $25^{\text {th }}$ Celebration Conference on Entrepreneurship and Innovation - Organizations, Institutions, Systems and Regions, Copenhagen.

Geroski, P.A., S Machin and J. Van Reenen (1993), "The Profitability of Innovating Firms", RAND Journal of Economics, 24(2), pp. 198-211.

Goldin, C. and L.F. Katz (2008), The Race Between Education and Technology, Harvard University Press, Cambridge, MA.

Graham, S.J.H., R.P. Merges, P. Samuelson and T. Sichelman (2009), "High Technology Entrepreneurs and the Patent System: Results of the 2008 Berkeley Patent Survey", Berkeley Technology Law Journal 24:1255-1328.

Griffith, R., S. Redding and J. Van Reenan (2004), "Mapping the Two Faces of R\&D: Productivity Growth in a Panel of OECD Industries", The Review of Economics and Statistics, 86(4), pp. 883-895. 
Griffith, R. and G. Macartney (2010), "Employment Protection Legislation, Multinational Firms and Innovation", CEPR Discussion Papers, No. 7628.

Goolsbee, A. (1999), “Does Government R\&D Policy Mainly Benefit Scientists and Engineers?”, American Economic Review 88(2), pp. 298-302.

Guellec, .D. and B. van Pottelsberghe de la Potterie (2003), “The Impact of Public R\&D Expenditure on Business R\&D”,. Economics of Innovation and New Technology, 12(3), pp. 225-243.

Hægeland, T. and J. Møen (2007), “The Relationship Between the Norwegian R\&D Tax Credit Scheme and Other Innovation Policy Instruments", Reports 2007/45, Statistisk sentralbyrå/Statistics Norway, Oslo-Kongsvinger.

Hall, R.E. (1991), “Labor Demand, Labor Supply, and Employment Volatility”, In NBER Macroeconomics Annual, 6, pp. 17-46

Hall, B.H. and J.M. Van Reenen (2000), "How Effective are Fiscal Incentives for R\&D? A Review of the Evidence", Research Policy 29: pp, 449-469.

Hall, B. and A. Maffioli (2008), "Evaluating the Impact of Technology Development Funds in Emerging Economies: Evidence from Latin America”, NBER Working Paper, no. 13835.

Hall, B.H. and J. Lerner (2009), "The Financing of R\&D and Innovation", NBER Working Paper No. 15325.

Hall, B., J. Mairesse and P. Mohnen (2010), "Measuring the Returns to R\&D", in Elsevier Handbook of the Economics of Innovation, B.H. Hall and N. Rosenberg (eds.), Burlington Academic Press.

Hall, B.H. and D. Harhoff (2012), Recent Research on the Economics of Patents. NBER Working Paper No. 17773

Haltiwanger, J., S. Scarpetta and H. Schweiger (2006), "Assessing Job Flows Across Countries: The Role of Industry, Firm Size and Regulations", IZA discussion paper No. 2450, Bonn.

Haltiwanger, J. (2011), "Firm Dynamics and Economic Performance", mimeo.

Hargreaves, I. (2011), Digital Opportunity: A Review of Intellectual Property and Growth, United Kingdom Intellectual Property Office.

Häussler, C., D. Harhoff and E. Müller (2012), "To Be Financed or Not - The Role of Patents for Venture Capital-Financing", ZEW - Centre for European Economic Research Discussion Paper No. 09-003.

Healy, P.M and K.G. Palepu (2001), "Information Asymmetry, Corporate Disclosure, and the Capital Markets: A Review of the Empirical Disclosure Literature", Journal of Accounting and Economics 31 (2001) pp. 405-440.

Henderson, R.M. and K.B. Clark (1990), "Architectural Innovation: The Reconfiguration of Existing Product Technologies and the Failure of Established Firms", Administrative Science Quarterly 35(1), pp. 9-30.

Henderson, R. (1993). "Underinvestment and Incompetence as Responses to Radical Innovation: Evidence from the Photolithographic Alignment Equipment Industry", RAND Journal of Economics. 24(2) pp. 248-270.

Holmes, T.J., D.K. Levine and J.A. Schmitz Jr. (2008), "Monopoly and the Incentive to Innovate When Adoption Involves Switchover Disruptions", NBER Working Paper 13864. 
Hsieh, C-T. and P. Klenow (2009), "Missallocation and Manufacturing TFP in China and India", Quarterly Journal of Economics 124(4), pp. 1403-1448.

Hsieh, C-T. and P. Klenow (2012), "The Life Cycle of Plants in India and Mexico", NBER Working Paper No. 18133

Hunter, L.C., E. Webster and A. Wyatt (2005), "Measuring Intangible Investment", Melbourne Institute Working Paper Series, No. 15/05, University of Melbourne.

Jarboe, K.P. (2008), "Building a Capital Market for Intangible Assets", Intellectual Asset Magazine, juinjuilllet, pp.30-35.

Jaumotte, F. and N. Pain (2005), "From Ideas to Development: The Determinants of R\&D and Patenting", OECD Economics Department Working Paper No. 457, OECD, Paris.

Johansson, Å. et al. (2012), "Long-Term Growth Scenarios", OECD Economics Department Working Paper No. 1000, OECD, Paris.

Jones, C.I. (2005), "Growth and Ideas", Chapter 16 in Handbook of Economic Growth, Vol. B, Edited by P. Aghion and S. Durlauf, Elsevier B.V., Dan Diego.

Karkinsky, T. and N. Riedel (2012), “Corporate Taxation and the Choice of Patent Location Within Multinational Firms", Journal of International Economics (88), pp. 176-185.

Kiyotaki, N. and J. Moore (1997), “Credit Cycles”, Journal of Political Economy 105, pp. 18-35.

Klapper, L., L. Laeven and R. Rajan (2006), "Entry Regulation as a Barrier to Entrepreneurship", Journal of Financial Economics, 82, pp. 591-629

Kortum, S. and J. Lerner (2000), “Assessing the Impact of Venture Capital on Innovation”, Rand Journal of Economics, 31, pp. 674-92.

Lemaire, J-P. (1996), "Sales Engineers Working on International Projects: Changing Patterns and Changing Roles", International Business Review, Winter, Vol. 5, issue 6, pp. 603-629.

Lerner, J. (1999), “The Government as a Venture Capitalist: The Long-Run Impact of the SBIR Program”, Journal of Business 72(3): pp. 285-318.

Lerner, J. (2002), "Patent Policy Shifts and Innovation over 150 Years", American Economic Review 92: pp. 221-225.

Lerner, J., (2008), "Boulevard Of Broken Dreams: Why Public Efforts To Boost Entrepreneurship And Venture Capital Have Failed", Princeton University Press, Princeton.

Lokshin, B. and P. Mohnen (2007), "Measuring the Effectiveness of R\&D Tax Credits in the Netherlands", CIRANO Working Papers from CIRANO.

Lokshin, B. and P, Mohnen (2008), "Wage Effects of R\&D Tax Incentives: Evidence from the Netherlands", UNU-MERIT Working Paper No. 34, University of Maastricht.

Lokshin, B. and P. Mohnen (2009), "How Effective Are Level-based R\&D Tax Credits ? Evidence from the Netherlands", Updated UNU-MERIT Working Paper No.29, University of Maastricht.

López-García, P., J.M. Montero and E. Moral-Benito (2012), "Business Cycles and Investment in Intangibles: Evidence from Spanish Firms", Banco de Espana Working Paper No. 1219. 
Loumioti, M. (2011), "The Use of Intangible Assets as Loan Collateral", Harvard Business School Job Market Paper.

Martin, J.P. and S, Scarpetta (2012), "Setting it Right: Employment Protection, Labour Reallocation and Prdoctivity”, De Economist, 160, pp. 89-166.

Melitz, M. (2003), “The Impact of Trade on Intra-Industry Reallocations and Aggregate Industry Productivity", Econometrica 71, pp. 1695-1725.

Melitz, M. and D. Trefler (2012), “Gains from Trade When Firms Matter”, Journal of Economic Perspectives 26(2), pp. 91-118.

Nunn, N. (2007), "Relationship-Specificity, Incomplete Contracts and the Pattern of Trade", Quarterly Journal of Economics, (122) 2, pp. 569-600.

OECD (2002), Frascati Manual: Proposed Standard Practice for Surveys on Research and Experimental Development. OECD, Paris

OECD (2006), Economic Policy Reforms: Going for Growth 2006 OECD, Paris.

OECD (2008), Intellectual Assets and Value Creation: A Synthesis Report, OECD publishing, Paris.

OECD (2009), OECD Science, Technology and Industry Scoreboard 2009, OECD, Paris.

OECD (2010), Innovation Strategy OECD, Paris.

OECD (2011a), OECD Science, Technology and Industry Scoreboard 2011, OECD, Paris.

OECD (2011b), “Financing High Growth Firms: The Role of Angel Investors”, OECD, Paris

OECD (2012), Better Skills, Better Jobs, Better Lives: A Strategic Approach to Skills Policies, OECD Paris.

OECD (2013a), "Taxation and Knowledge Based Capital: Policy Considerations in a Globalised Economy", (CTPA/CFA(2013)2).

OECD (2013b), OECD Reviews of Innovation Policy: Knowledge-based Start-ups in Mexico, OECD Publishing, Paris.

Olley, G.S and A. Pakes (1996), "The Dynamics of Productivity in the Telecommunications Equipment Industry", Econometrica, 64(6), pp. 1263-97.

Parente, S.L. and E.C. Prescott (2000), Barriers to Riches, MIT Press: Cambridge, MA.

Park, W.G. (2008), “International Patent Protection: 1960-2005”, Research Policy, 37, pp. 761-766

Parsons, M. and N. Phillips (2007), “An Evaluation of the Federal Tax Credit for Scientific Research and Experimental Development”, Canadian Dept. of Finance Working Paper 2007-08.

Peng, M.W., Y. Yamakawa and S.H. Lee (2010), "Bankruptcy Laws and Entrepreneur Friendliness", Entrepreneurship Theory and Practice, 34, pp. 517-530.

Pinto Ribeiro, S., S. Menghinello and K. D. Backer (2010), "The OECD ORBIS Database: Responding to the Need for Firm-Level Micro-Data in the OECD”, OECD Statistics Working Papers, 2010/1, OECD Publishing.

Rajan, R. and L. Zingales (1998), "Financial Dependence and Growth”, American Economic Review, 88(3), pp. 559-86. 
Roth, A.E. (2008), "What Have We Learned From Market Design?", Hahn Lecture, Economic Journal, No. 118 (March), pp. 285-310.

Samila, S. and O. Sorenson (2011), "Venture Capital, Entrepreneurship and Economic Growth", Review of Economics and Statistics, 93(1), pp. 338-349.

Schmitz, J.A., Jr. (2005), "What Determines Productivity? Lessons from the Dramatic Recovery of the U.S. and Canadian Iron Ore Industries following Their Early 1980s Crisis", Journal of Political Economy, 113(3), pp. 582-625.

Schmookler, J. (1966), Invention and Economic Growth (Cambridge, MA: Harvard University Press).

Schumpeter, J.A. (1942), Capitalism, Socialism and Democracy, New York: Harper.

Shane, S. (2001), “Technology Regimes and New Firm Formation”, Management Science, 47(9), 1173 1190.

Shapiro, C. (2001), "Navigating the Patent Thicket: Cross-licenses, Patent Pools, and Standard-Setting", in: Jaffe, A., Lerner, J. and Stern, S. (eds.), Innovation Policy and the Economy, Vol. 1. MIT Press for the National Bureau of Economic Research.

Sheehan, J. and A. Wyckoff (2003), “Targeting R\&D: Economic and Policy Implications of Increasing R\&D Spending", OECD Science, Technology and Industry Working Papers, 2003/08, OECD, Paris.

Tushman, M.L. and P. Anderson (1986), "Technological Discontinuities and Organizational Environments", Administrative Science Quarterly, 31: pp. 439-465.

UK IPO ( 2011), “Patent Thickets: An Overview”, http://www.ipo.gov.uk/informatic-thickets.pdf

van Ark, B., M. O’Mahony and M.P. Timmer (2008), “The Productivity Gap between Europe and the United States: Trends and Causes", Journal of Economic Perspectives 22(1): pp. 25-44.

van Ark, B., J.X. Hao, C. Corrado and C. Hulten (2009), "Measuring Intangible Capital and its Contribution to Economic Growth in Europe", EIB Papers 14(1), pp.62-93.

Warda, J. (2001), "Measuring the Value of R\&D Tax Treatment in OECD Countries", OECD STI Review, No. 27, pp.185-211.

Wasmer, E. (2006), "Interpreting Europe-US Labor Market Differences: the Specificity of Human Capital Investments", American Economic Review, 96(3), pp. 811-31.

Westmore, B. (2013), "R\&D, Patenting and Productivity: The Role of Public Policy", OECD Economics Department Working Paper, No. 1047, OECD, Paris.

Wilson, K. and F. Silva (2013), "Policies for Seed and Early Stage Finance: Summary of the 2012 OECD Financing Questionnaire”, OECD DSTI Working Paper forthcoming.

Ziebarth, N.L. (2012), “Misallocation and Productivity during the Great Depression”, Mimeo. 